Prepared in cooperation with the U.S. Army Corps of Engineers

\title{
Sediment Transport and Deposition in the Lower Missouri River During the 2011 Flood
}

Chapter F of 2011 Floods of the Central United States

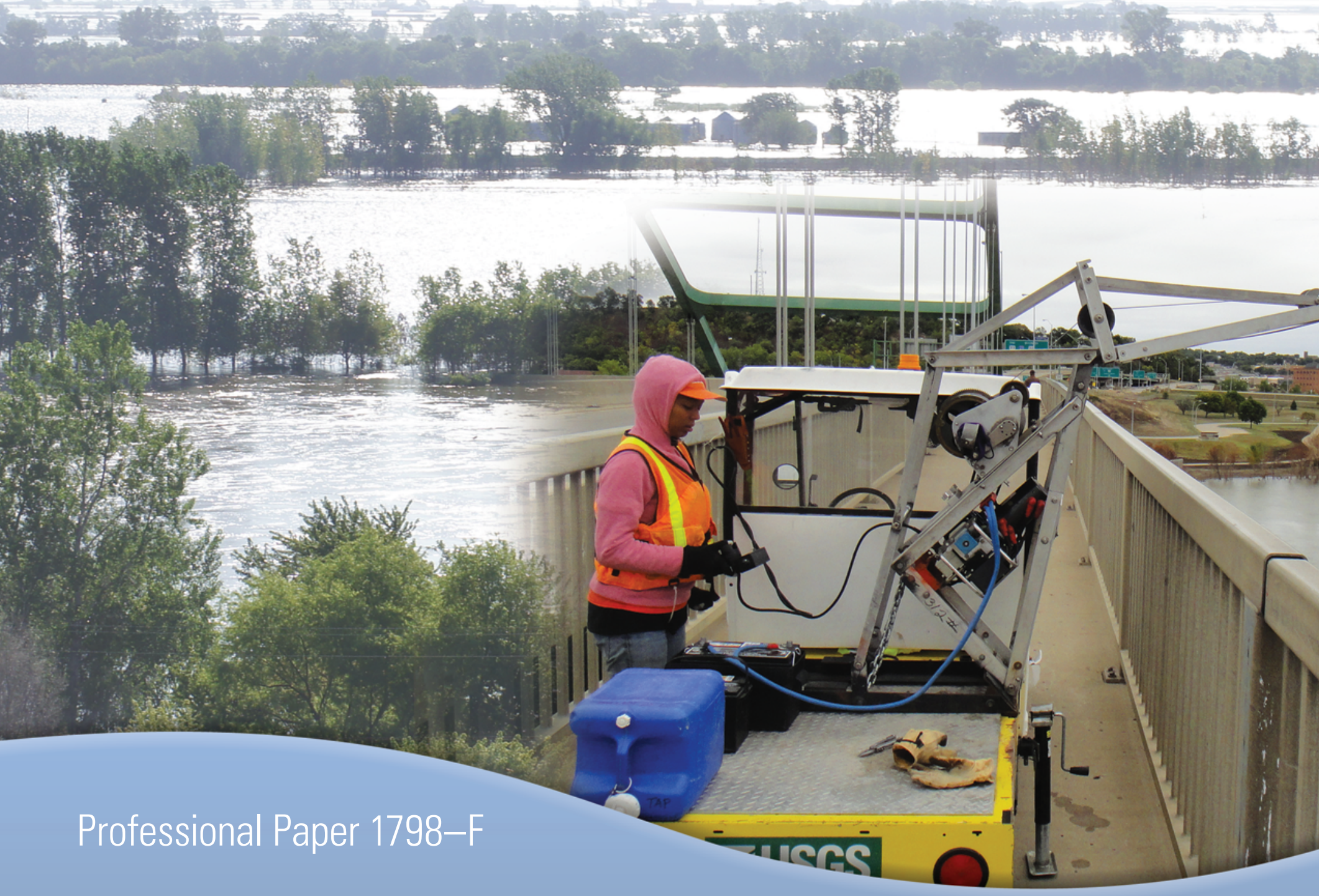

U.S. Department of the Interior

U.S. Geological Survey 
Front cover. Top photograph: View of flooding from Nebraska City, Nebraska, looking east across the Missouri River, August 2, 2011. Photograph by Robert Swanson, U.S. Geological Survey.

Right photograph: USGS scientist collecting a sediment sample from the Missouri River at Sioux City, lowa, September 16, 2011. Photograph by Ryan Tompkins, U.S. Geological Survey.

Back cover. Sand from the 2011 flood on the flood plain in northwestern Missouri, September 22, 2012. Photograph by Robert Jacobson, U.S. Geological Survey. 


\section{Sediment Transport and Deposition in the Lower Missouri River During the 2011 Flood}

By Jason S. Alexander, Robert B. Jacobson, and David L. Rus

Chapter F of

2011 Floods of the Central United States

In cooperation with the U.S. Army Corps of Engineers

Professional Paper 1798-F 


\title{
U.S. Department of the Interior SALLY JEWELL, Secretary
}

\section{U.S. Geological Survey Suzette M. Kimball, Acting Director}

\author{
U.S. Geological Survey, Reston, Virginia: 2013
}

For more information on the USGS - the Federal source for science about the Earth, its natural and living resources, natural hazards, and the environment, visit http://www.usgs.gov or call 1-888-ASK-USGS.

For an overview of USGS information products, including maps, imagery, and publications, visit http://www.usgs.gov/pubprod

To order this and other USGS information products, visit http://store.usgs.gov

Any use of trade, firm, or product names is for descriptive purposes only and does not imply endorsement by the U.S. Government.

Although this information product, for the most part, is in the public domain, it also may contain copyrighted materials as noted in the text. Permission to reproduce copyrighted items must be secured from the copyright owner.

Suggested citation:

Alexander, J.S., Jacobson, R.B., and Rus, D.L., 2013, Sediment transport and deposition in the lower Missouri River during the 2011 flood: U.S. Geological Survey Professional Paper 1798-F, 27 p., http://dx.doi.org/10.3133/pp1798F. 


\section{Contents}

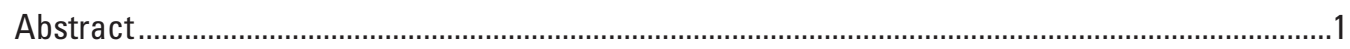

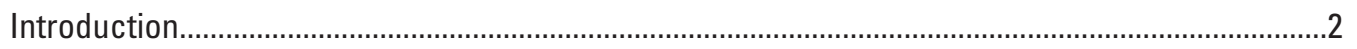

Importance of Understanding Sediment Transport in the Lower Missouri River .....................3

General Morphologic and Hydrologic Characteristics of the Lower Missouri River ...............5

Measurement and Monitoring of Sediment Transport in the Lower Missouri River ................5

Sediment Transport and Deposition in the Lower Missouri River in 2011 .......................................6

Temporal and Spatial Characteristics of Sediment Transport in the Lower Missouri River

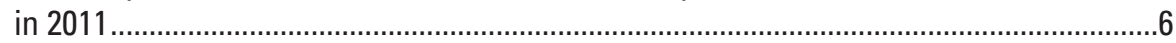

Suspended-Sediment Concentration ...............................................................................

Washload ......................................................................................................................

Suspended Load .................................................................................................................9

Comparison of Sediment Transport in 2011 with Other Recent Floods.....................................11

Patterns of Sediment Deposition Along the Lower Missouri River during the Flood of

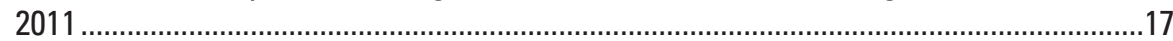

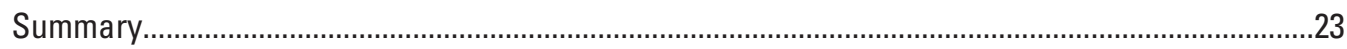

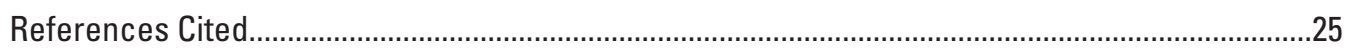

\section{Figures}

1. Map showing the Missouri River Basin, associated physiographic provinces, primary tributaries, main-stem dams, and suspended-sediment monitoring stations along lower Missouri River.

2. Graphs showing frequency distribution of selected measurements of suspendedsediment concentration at streamgages along the lower Missouri River, and daily streamflow of major tributaries upstream from each measurement location, January 1 to October 1, 2011.

3. Graphs showing frequency distribution of measured percentage of suspendedsediment as washload (percentage of suspended-sediment mixture finer than 0.0625 millimeter in diameter) at selected streamgages along the lower Missouri River and daily streamflows of major tributaries upstream from each measurement location, January 1 to October 1, 2011

4. Graphs showing frequency distributions of sampled suspended-sediment concentrations for selected streamgages along the lower Missouri River for low- and highaction streamflows in water year 2011 and in the preceding 20 water years.....

5. Pie charts showing relative contributions of tributary streamflow to annual average streamflow of the Missouri River at Hermann, Missouri (U.S. Geological Survey streamgage number 06934500), during water years 1993, 2008, and 2011, and average for the 20-year period-of-record preceding water year 2011, as percentage of total

6. Diagrams showing annual average streamflow for the lower Missouri River and major tributaries and annual total suspended-sediment discharge for selected mainstem streamgages, water years 1993, 2008, and 2011

7. Areal images showing method of mapping sand deposition and deposited sand on the flood plain of the lower Missouri River, upstream of Sioux City, lowa, in Union County, lowa after the flood conditions of 2011 
8. Graphs showing longitudinal distribution of sand deposition and overbank flooding along the lower Missouri River in 2011 and potential covariates..

9. Conceptual diagrams showing progression of levee-break ..........................................21

10. Multispectral satellite image taken in Novermber 2011 showing a typical levee-break complex fromed in the valley bottom of the lower Missouri River valley during overbank flooding in 2011

11. Graph showing cumulative sand depositional area by distance away from channel boundary in the valley bottom of seven hydrologic segments of the lower Missouri River after overbank flooding in 2011

\section{Table}

1. Magnitude and excedance frequency of annual average and peak streamflows, annual average suspended-sediment concentration, and annual total suspended-sediment discharge for selected main-stem and tributary streamgages, lower Missouri River, water year 2011

Rock jetty in Plattsmouth backwater on the Missouri River near Plattsmouth, Nebraska, October 24, 2011. Photograph by Justin Krahulik, U.S. Geological Survey. 


\section{Conversion Factors}

\begin{tabular}{|c|c|c|}
\hline Multiply & By & To obtain \\
\hline \multicolumn{3}{|c|}{ Length } \\
\hline inch (in.) & 25.4 & millimeter $(\mathrm{mm})$ \\
\hline foot $(\mathrm{ft})$ & 30.48 & centimeter $(\mathrm{cm})$ \\
\hline foot $(\mathrm{ft})$ & 0.3048 & meter $(\mathrm{m})$ \\
\hline mile (mi) & 1.609 & kilometer (km) \\
\hline \multicolumn{3}{|c|}{ Area } \\
\hline acre & 0.4047 & hectare (ha) \\
\hline acre & 0.004047 & square kilometer $\left(\mathrm{km}^{2}\right)$ \\
\hline \multicolumn{3}{|c|}{ Volume } \\
\hline ounce, fluid (fl. oz) & 0.02957 & liter $(\mathrm{L})$ \\
\hline cubic foot $\left(\mathrm{ft}^{3}\right)$ & 28.32 & cubic decimeter $\left(\mathrm{dm}^{3}\right)$ \\
\hline cubic foot $\left(\mathrm{ft}^{3}\right)$ & 0.02832 & cubic meter $\left(\mathrm{m}^{3}\right)$ \\
\hline cubic yard $\left(\mathrm{yd}^{3}\right)$ & 0.7645 & cubic meter $\left(\mathrm{m}^{3}\right)$ \\
\hline acre-foot (acre-ft) & 1,233 & cubic meter $\left(\mathrm{m}^{3}\right)$ \\
\hline \multicolumn{3}{|c|}{ Flow rate } \\
\hline cubic foot per second $\left(\mathrm{ft}^{3} / \mathrm{s}\right)$ & 0.02832 & cubic meter per second $\left(\mathrm{m}^{3} / \mathrm{s}\right)$ \\
\hline \multicolumn{3}{|c|}{ Mass } \\
\hline ounce, avoirdupois (oz) & 28350 & milligram (mg) \\
\hline ounce, avoirdupois (oz) & 28.35 & $\operatorname{gram}(\mathrm{g})$ \\
\hline ton per day (ton/d) & 0.9072 & metric ton per day \\
\hline ton per day (ton/d) & 0.9072 & metric ton per day \\
\hline ton per day (ton/d) & 0.9072 & megagram per day $(\mathrm{Mg} / \mathrm{d})$ \\
\hline ton per year (ton/yr) & 0.9072 & megagram per year $(\mathrm{Mg} / \mathrm{yr})$ \\
\hline ton per year (ton/yr) & 0.9072 & metric ton per year \\
\hline \multicolumn{3}{|c|}{ Concentration } \\
\hline Milligram per liter (mg/L) & 1 & part per million \\
\hline Milligram per liter (mg/L) & 0.058 & grain per gallon \\
\hline
\end{tabular}

Horizontal coordinate information is referenced to the North American Datum of 1983 (NAD 83). 



\title{
Sediment Transport and Deposition in the Lower Missouri River During the 2011 Flood
}

\author{
By Jason S. Alexander, Robert B. Jacobson, and David L. Rus
}

\begin{abstract}
Floodwater in the Missouri River in 2011 originated in upper-basin regions and tributaries, and then travelled through a series of large flood-control reservoirs, setting records for total runoff volume entering all six Missouri River main-stem reservoirs. The flooding lasted as long as 3 months. The U.S Geological Survey (USGS) examined sediment transport and deposition in the lower Missouri River in 2011 to investigate how the geography of floodwater sources, in particular the decanting effects of the Missouri River main-stem reservoir system, coupled with the longitudinal characteristics of civil infrastructure and valley-bottom topography, affected sediment transport and deposition in this large, regulated river system.

During the flood conditions in 2011, the USGS, in cooperation with the U.S. Army Corps of Engineers, monitored suspended-sediment transport at six primary streamgages along the length of the lower Missouri River. Measured suspended-sediment concentration (SSC) in the lower Missouri River varied from approximately 150 milligrams per liter (mg/L) to 2,000 mg/L from January 1 to September 30, 2011. Median SSC increased in the downstream direction from $355 \mathrm{mg} / \mathrm{L}$ at Sioux City, Iowa, to $490 \mathrm{mg} / \mathrm{L}$ at Hermann, Missouri. The highest SSCs were measured downstream from Omaha, Nebraska, in late February when snowmelt runoff from tributaries, which were draining zones of highsediment production, was entering the lower Missouri River, and releases of water at Gavins Point Dam were small. The
\end{abstract}

combination of dilute releases of water at Gavins Point Dam and low streamflows in lower Missouri River tributaries caused sustained lowering of SSC at all streamgages from early July through late August.

Suspended-sediment ranged from 5 percent washload (PW; percent silt and clay) to as much as 98 percent in the lower Missouri River from January 1 to September 30, 2011. Median PW increased in the downstream direction from 24 percent at Sioux City, Iowa, to 78 percent at Hermann, Missouri. Measurements made in early January, when SSC was low, indicate that suspended sediment mostly was composed of bed material, but by mid-February, runoff from the plains caused PW to increase at most streamgages. Total suspendedsediment discharge (SSD) during water year 2011 at the selected streamgages in the lower Missouri River ranged from approximately 29 to 64 million tons. Total estimated SSD had the lowest exceedance frequencies in the reaches between Gavins Point Dam and Nebraska City, Nebraska, but exceedance frequencies increased substantially downstream. In 2011, total SSD with low exceedance frequencies were reported at Sioux City, Iowa, Omaha, Nebraska, and Nebraska City, Nebraska, despite moderate-to-high exceedance frequencies for annual average SSC, indicating that the duration of highmagnitude flooding was the primary driver of total SSD.

Comparison of median SSC for samples from water year 2011 with samples in the 20 years prior indicated that median SSC for high-action streamflows (streamflows likely to produce a stage exceeding the National Weather Service's "action stage") in 2011 were lower than those typical for high-action

Sand from the 2011 flood on the flood plain in northwestern Missouri, September 22, 2012. Photograph by Robert Jacobson, U.S. Geological Survey. 
streamflows. Multiple-comparison analysis indicated that median SSC values for low-action streamflows (streamflows likely to produce stages lower than the National Weather Service's "action stage") and high-action streamflows sampled in 2011 at 4 of 6 streamgages were not significantly distinguishable from median SSC values for low-action streamflows in the previous 20 years. Longitudinal comparison of streamflow and SSD exceedance frequencies for 2011 with corresponding frequencies for 2008 and 1993 indicated the important role of tributary contributions to total SSD in the lower Missouri River. In 1993 and 2008, tributaries were the primary source of floodwater in the lower Missouri River, which resulted in a 20-fold increase in total SSD from Sioux City, Iowa, to Hermann, Missouri. In 2011, releases at Gavins Point Dam were the primary source of floodwater in the lower Missouri River, and total SSD at Hermann, Missouri, was only twice that estimated for Sioux City, Iowa.

Sand deposition was estimated using analysis of multispectral satellite imagery collected in October and November 2011. Distributions of sand in the flood plain of the lower Missouri River also were quantified in relation to distance from the banks of the main channel for seven discrete river segments bounded by Gavins Point Dam and selected downstream tributaries. The areal extent of overbank flooding and flood-plain sand deposits increased downstream from Sioux City, Iowa to a broad peak near Rulo, Nebraska, and then decreased to levels near the lower limit of quantification downstream from Kansas City, Missouri. Most of the flood plain inundation and sediment-deposition damage to agricultural fields was observed between river miles 480 and 700 , where 2011 peak streamflows had low exceedance frequencies, and the lower Missouri River channel was less incised or had aggraded recently. As channel capacity increased in the downstream direction, the relative magnitude of the flood decreased downstream, and overbank flooding was less extensive. In the constricted reaches, flood-plain sand deposits mainly were observed in association with levee breaks.

\section{Introduction}

Sediment transported with floodwater can cause substantial damage to agricultural fields, homes, and infrastructure along the valley bottom adjacent to the river. Sediment trapped behind dams also decreases storage capacity and reduces the viable lifespan of flood-control reservoirs (Graf and others, 2010); however, the transport and deposition of sediment can be an important driver of ecosystem processes, particularly during large, landscape-scale disturbances such as floods, which often rejuvenate existing channel and flood-plain habitats, and construct new physical templates for riverine and riparian habitats (Junk and others, 1989; Scott and others, 1996). Thus, understanding processes of sediment transport and deposition in large rivers is crucial to striking a balance between protecting infrastructure, agriculture, and urban areas adjacent to the river while also sustaining natural physical processes that are important to ecosystems of value to the Nation.

Flooding along rivers in the central United States was widespread in 2011 (Holmes and others, 2013). Flooding in the Missouri River Basin in 2011 was caused by a combination of above-normal snowpack in headwater regions in the Rocky Mountains of Montana and Wyoming, near record snowfall and wet soil conditions on the plains, and record rainfall in May across the upper Missouri River Basin (Vining and others, 2013; Grigg and others, 2012). Total volume of runoff from these conditions into all six Missouri River main-stem reservoirs in 2011 was the most since record keeping began, exceeding previous peaks set in 1881 (50 million acre-feet) and 1997 (49 million acre-feet) by more than 10 million acrefeet, and forcing releases of record high-magnitude streamflows from several of the main-stem dams operated by the U.S. Army Corps of Engineers (USACE). Releases at Gavins Point Dam near Yankton, South Dakota, the most downstream dam in the Missouri River main stem, equaled or exceeded 150,000 cubic-feet per second $\left(\mathrm{ft}^{3} / \mathrm{s}\right)$ from mid-June through late August, and were the largest measured in magnitude and volume since operations began in 1955 (Grigg and others, 2012).

Flooding in the Missouri River in 2011 transported and deposited large quantities of sediment and the U.S. Geological Survey (USGS) monitored the characteristics of sediment transport in the Missouri River at several streamgages along the main stem from Montana to Missouri (Galloway and others, 2013; U.S. Geological Survey, 2012a); however, the effects of floodwater geography (that is, where floodwaters originate within a large river basin) on sediment transport were most apparent in the floodwater of the Missouri River downstream from Gavins Point Dam (hereafter referred to as "lower Missouri River"), where substantial sediment deposition and damage to adjacent properties was observed (Grigg and others, 2012).

The USGS, in cooperation with the U.S. Army Corps of Engineers, examined sediment transport and deposition in the lower Missouri River in 2011 to investigate how the geography of floodwater sources, coupled with the alongstream characteristics of civil infrastructure and valley-bottom topography, affected characteristics of sediment transport and deposition in this large, regulated river system. Investigation of sediment transport and deposition focused on three key questions related to the unique combination of floodwater geography, magnitude, and volume in the lower Missouri River during 2011: (1) What were the temporal and spatial characteristics of sediment transport in the lower Missouri River in 2011? (2) How did floodwater geography differ from other high streamflow years in the lower Missouri River and did the difference cause detectable differences in sediment transport relative to previous years? (3) How did the longitudinal variation in channel geomorphology and civil infrastructure interact with floodwater geography to affect the spatial distribution and style of sediment deposition in the lower Missouri River valley? 


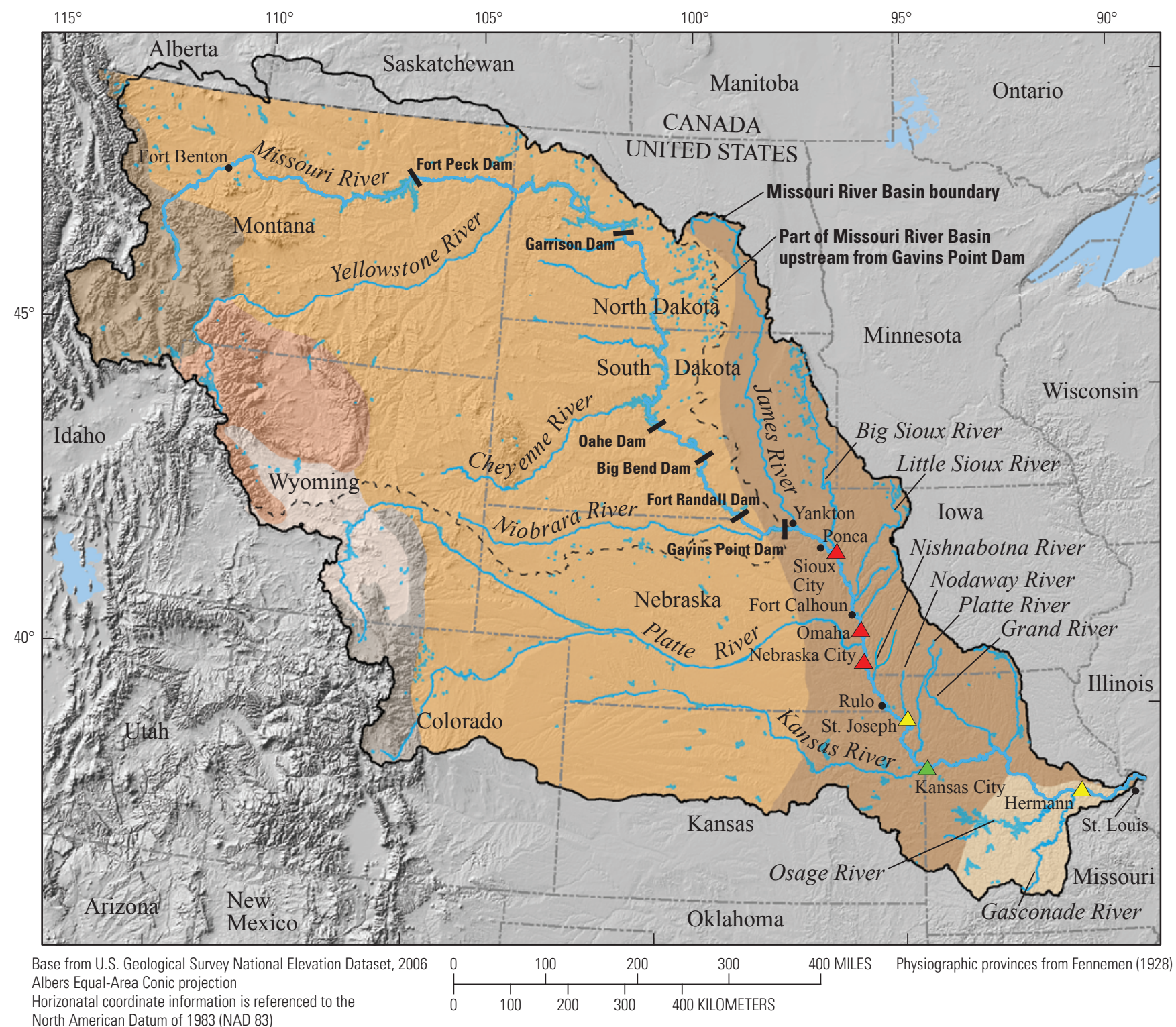

EXPLANATION

Physiographic provinces within Missouri River Basin

Central Lowland

Great Plains

Middle Rocky Mountains

Northern Rocky Mountains
Ozark Plateaus

Southern Rocky Mountains

Wyoming Basin
- Main-stem dam

$\triangle$ Daily suspended-sediment monitoring station

$\triangle$ Continuous suspended-sediment monitoring station

$\triangle$ Periodic suspended-sediment monitoring station

Figure 1. The Missouri River Basin, associated physiographic provinces, primary tributaries, main-stem dams, and suspendedsediment monitoring stations along the lower Missouri River.

\section{Importance of Understanding Sediment Transport in the Lower Missouri River}

The Missouri River Basin encompasses all or portions of 10 U.S. States and two Canadian Provinces, and composes roughly 43 percent of the total Mississippi River Basin land area. The Missouri River Basin encompasses several physiographic provinces (fig. 1), each with differing topographic relief and surficial materials. Most of the Missouri River Basin lies within the Great Plains and Central Lowland physiographic provinces (Fennemen, 1928), which broadly are characterized by gently sloping, unconsolidated, easily erodible fine sediments (sand, silt, and clay). Despite its vast expanse, the Missouri River contributes only about 12 percent of the total average annual streamflow of the Mississippi River Basin because much of its watershed is semi-arid (Meade, 1995); 
however, the landscapes of the Great Plains and Central Lowland physiographic provinces produce an abundance of sediment relative to annual water runoff (Langbein and Schumm, 1958) and, consequently, the Missouri River is the largest source of sediment to the Mississippi River system (Heimann and others, 2011) despite the large number of dams and reservoirs. The sediment-laden, turbid waters of the Missouri River were the source of the original nickname "Big Muddy" given to the Missouri River by early explorers, trappers, boatmen, and settlers in the region (Blevins, 2006).

The Missouri River main-stem reservoir system (MRMRS) was constructed between 1933 and 1964, and consists of six large earthen dams blocking lengths of the main channel of the Missouri River between Fort Benton, Mont, and Yankton, South Dakota (fig. 1) (National Research Council, 2002). Approximately one-half of the Missouri River Basin lies upstream from the most downstream impoundment, Gavins Point Dam (fig. 1). Sediment trapping by reservoirs within the MRMRS has disrupted the supply of sediment to the segments between dams in the middle Missouri River, and along the lower Missouri River. Primary sediment sources to the lower Missouri River are now limited to tributary contributions from the eastern regions of South Dakota and Nebraska, northeastern Kansas, western Iowa, and northwestern and central Missouri (fig. 1). The sediment-supply disruption created by MRMRS has caused channel incision in the reaches below the dams, and reduced sediment delivery to the Mississippi River by more than one-half of the estimated pre-settlement rate (Jacobson and others, 2009; Heimann and others, 2010). Since the pronounced disruption in sediment transport coinciding with completion of the MRMRS, streamflowweighted suspended-sediment concentrations in the lower
Missouri River have continued to decline at rates between 2 and 3 percent per year (Heimann and others, 2011). Although the primary mechanisms are still poorly quantified, continued declines in sediment loads have been attributed to improved agricultural tillage and soil conservation practices (Meade and Moody, 2010; U.S. Department of Agriculture, 2012).

The reductions in sediment transport and water turbidity, in combination with alterations of river-channel morphology, have reduced the quality and extent of natural riverine habitats in the lower Missouri River, and have been implicated as causes for the decline of some fish and bird species native to the Missouri River ecosystem (National Research Council, 2002; Blevins, 2011). Riverbed incision, particularly in the reaches of the Missouri River just downstream from Gavins Point Dam, has affected recreation facilities, municipal and power-generation water intakes and well fields, and tributary channel stability, and has disconnected the river from its flood plain, preventing natural rejuvenation of flood-plain forest and wetland habitat and preventing deposition of nutrients in the valley bottom (U.S. Army Corps of Engineers, 2006; Dixon and others, 2010). Channel straightening, narrowing, and bank stabilization created a deeper, self-scouring navigation channel, and have reduced the area of emergent sand, a primary nesting habitat feature for migratory birds (Funk and Robinson, 1974; Hallberg and others, 1979). The reduction in sediment delivery to the Mississippi River also has been cited as one of several stressors contributing to the decline of coastal wetlands in the Mississippi River Delta system (not shown in fig. 1) (National Research Council, 2011). Habitat recovery and restoration efforts are ongoing in the lower Missouri River, as well as coastal Louisiana (National Research Council, 2011; U.S. Army Corps of Engineers, 2009). Proposed

\section{Langdon backwater on the Missouri River near Nemaha, Nebraska, looking upstream from the mouth, 0ctober 24, 2011. Photograph by Justin Krahulik, U.S. Geological Survey.}


restoration options have included sediment nourishment projects to replenish diminished supplies, including an engineered sediment routing to the lower Missouri River downstream from Gavins Point Dam (Coker and others, 2009).

\section{General Morphologic and Hydrologic Characteristics of the Lower Missouri River}

Downstream from the MRMRS to St. Louis, Missouri, the lower Missouri River can be divided broadly into three distinct sub-segments based on channel engineering and levee confinement: (1) an unchannelized and unconfined segment from Gavins Point Dam to approximately Ponca, Nebraska; (2) a channelized and partially-confined segment from approximately Ponca to Fort Calhoun, Nebr.; and (3) a channelized and confined segment from Fort Calhoun to St. Louis, Mo. From Gavins Point Dam at river mile 811.1 (RM 811.1, miles upstream from the confluence with the Mississippi River along the Missouri River channel, based on unpublished data from the U.S. Army Corps of Engineers) to approximately Ponca, Nebr. (RM 753), the lower Missouri River is unchannelized, has numerous midchannel sandbars and islands, and has high bank-erosion rates relative to segments downstream (Elliot and Jacobson, 2006). River-channel width in the unchannelized and unconfined segment varies from approximately 600 to 6,000 feet (ft). Downstream from RM 753, the lower Missouri River has been engineered into a roughly uniform, narrow, self-scouring channel to support barge navigation (referred to as "the navigation channel"), is deeper than segments upstream, and channel width varies from only about 600 to 1,000 ft (National Research Council, 2002). Between RM 753 and approximately Fort Calhoun, Nebr. (RM 634), there are no Federal levees on the flood plain, except near Sioux City, Iowa, and the valley bottom is wide, so the lower Missouri River is less confined during overbank streamflows than segments downstream, but overbank streamflows are less likely because the valley bottom is high relative to the channel bottom (Jacobson and others, 2007). Downstream from RM 634, the valley bottom narrows, and the system of Federal and private levees confines the lower Missouri River from Omaha, Nebr, to St. Louis, Mo.

The width and elevation of the lower Missouri River channel have changed in response to shifts in sediment supply and hydrology associated with completion of the MRMRS, channelization, and within-channel sand extraction (Jacobson and others, 2009). These changes in channel morphology have caused spatially variable changes to the conveyance capacity of the lower Missouri River channel. Between Gavins Point Dam and Sioux City, Iowa, the river channel has incised by as much as $10 \mathrm{ft}$ since completion of the MRMRS (U.S. Army Corps of Engineers, 2006). Between Ponca, Nebr., and Sioux City, Iowa, channel degradation has offset decreases in channel capacity associated with flood-plain encroachment into the channel (narrowing) (U.S. Army Corps of Engineers, 2006), and streamflows of as much as $70,000 \mathrm{ft}^{3} / \mathrm{s}$ cause only minor flood damage (Grigg and others, 2012). Downstream from
Sioux City, Iowa, the magnitude of incision of the lower Missouri River channel since completion of the MRMRS gradually decreases and the lower Missouri River is channelized completely. Between Sioux City, Iowa, and Omaha, Nebr., the combination of progressively decreasing incision and floodplain encroachment has decreased the conveyance capacity of the lower Missouri River relative to upstream segments, and minor flooding here begins at streamflows exceeding approximately $65,000 \mathrm{ft}^{3} / \mathrm{s}$ (U.S. Army Corps of Engineers, 2006). Between Omaha, Nebr., and St. Joseph, Mo., the lower Missouri River channel has lost conveyance capacity in recent decades because of flood-plain encroachment and channel aggradation, and flooding begins at streamflows exceeding approximately $90,000 \mathrm{ft}^{3} / \mathrm{s}$. Despite the system of levees in place downstream from Omaha, Nebr., flooding of agricultural land in the segment between Omaha and St. Joseph, Mo., begins at river stages $2 \mathrm{ft}$ below the official flood stage because the height of the adjacent valley bottom is closer to the channel-bottom elevation relative to upstream reaches, and the valley bottom is poorly drained (U.S. Army Corps of Engineers, 2006; Chojnacki and others, 2012). Downstream from St. Joseph, Mo., patterns of channel incision and aggradation are variable, but flooding does not begin until streamflows exceed approximately 150,000 ft³ $/ \mathrm{s}$ (U.S. Army Corps of Engineers, 2006).

\section{Measurement and Monitoring of Sediment Transport in the Lower Missouri River}

Sediment transport in rivers is measured in two primary modes: (1) suspended load, and (2) bedload. Numerous sediment-sampling devices have been tested, approved, and are associated with measurement methods standardized by a multi-agency U.S. government entity referred to as the Federal Interagency Sedimentation Program (FISP). The reader is referred to Edwards and Glysson (1999) for detailed descriptions of standard sediment-sampling devices, associated theory, and sampling methods.

Most of the sediment load of the lower Missouri River is transported in suspension (National Research Council, 2011; Galloway and others, 2013). The suspended-sediment concentration (SSC) was obtained from water samples that represent the vertical and horizontal variability of suspended-sediment in the river channel. Samples typically were collected across the entire vertical water column at multiple locations along a river transect by lowering a standard, approved sampler (Davis, 2005) from the water surface down to a sampler-specific point just above the streambed (from 0.5 to $2 \mathrm{ft}$ ) before raising the sampler back up again, with the sampler transited vertically at a constant rate (Edwards and Glysson, 1999). In large turbid rivers, the sampler often is not lowered to the point of contact with the riverbed to prevent the sampler nozzle from sampling the riverbed. As a consequence, there often is an enlarged "unsampled zone," which may result in underestimation of SSC. The subsamples collected at each location along the transect were either composited into one sample or 
analyzed separately for SSC (Guy, 1969; Edwards and Glysson, 1999). Suspended-sediment samples were analyzed at the USGS laboratories in Iowa City, Iowa, and Rolla, Mo.

In the lower Missouri River, suspended sediment was monitored at selected USGS streamgages where the streamflow of the river is measured continually or easily computed from a statistical relation with river stage. The USGS used three types of sediment monitoring in the lower Missouri River: (1) daily, (2) continuous, and (3) periodic (fig. 1). Daily monitoring happens at streamgages where a daily value of SSC and suspended-sediment load (SSL) are computed using methods described in Porterfield (1972), which generally employ a combination of frequent (typically 2 to 3 times per week) sampling of SSC, as well as statistical relations between streamflow and SSC (Horowitz, 2003). Continuous monitoring is a type of daily monitoring where the daily record of SSC and SSL were computed using continuous measurements (at most one measurement recorded every 15 minutes) of a surrogate(s), usually turbidity (Rasmussen and others, 2009), for which a statistical model of the relation to SSC subsequently is developed using frequent samples of SSC. Periodic monitoring happens at streamgages where the river was sampled for SSC at varying frequencies, and no daily record was computed. Periodic SSC data were not considered adequate for computation of daily SSL, but were considered sufficient to compute annual SSL using multivariate statistical approaches (Runkel and others, 2004).

During the flood conditions in 2011, the USGS, in cooperation with the U.S. Army Corps of Engineers, monitored suspended-sediment transport at six primary streamgages along the length of the lower Missouri River: (1) Sioux City, Iowa (USGS streamgage 06486000); (2) Omaha, Nebr. (USGS streamgage 06610000); (3) Nebraska City, Nebr. (USGS streamgage 06807000); (4) St. Joseph, Mo. (USGS streamgage 06818000); (5) Kansas City, Mo. (USGS streamgage 06893000); and (6) Missouri River at Hermann, Mo. (USGS streamgage 06934500). These stations are hereinafter referred to simply as "Sioux City," "Omaha," "Nebraska City," "St. Joseph," "Kansas City," and "Hermann," respectively, or collectively as "the selected streamgages." Five of the six selected streamgages in the lower Missouri River have daily or continuous monitoring for sediment, and Kansas City has periodic monitoring (fig. 1). Bedload sediment transport also was measured periodically at several streamgages along the lower Missouri River in 2011 (Galloway and others, 2013).

\section{Sediment Transport and Deposition in the Lower Missouri River in 2011}

Investigation of sediment transport and deposition focused on three key questions related to the unique combination of floodwater geography, streamflow magnitude, and volume in the lower Missouri River in 2011: (1) What were the temporal and spatial characteristics of sediment transport in the lower Missouri River in 2011? (2) How did floodwater geography in 2011 differ from other high streamflow years in the lower Missouri River, and did the difference in geography cause detectable differences in sediment transport relative to previous years? (3) How did the longitudinal variation in channel geomorphology and civil infrastructure interact with floodwater geography to affect the spatial distribution and style of sediment deposition in the lower Missouri River valley?

\section{Temporal and Spatial Characteristics of Sediment Transport in the Lower Missouri River in 2011}

For the purpose of describing the characteristics of suspended-sediment transport in the lower Missouri River during the high-streamflow conditions of 2011, three measures were used: (1) SSC; (2) washload, as a percentage of SSC (PW); and (3) suspended-sediment discharge (SSD), sometimes called the "suspended load." For the purposes of the analysis described in this report, the term "washload" refers to the fraction of particles in a suspended-sediment mixture that are finer than 0.0625 millimeters ( $\mathrm{mm}$ ), also referred to as "silt and clay," or collectively as "mud." Washload particles typically are considered to be derived from upland and bank erosion, and may travel in perpetual suspension in the water column, whereas sand and other coarser particles are considered to be derived mostly from the riverbed and travel intermittently in suspension or in frequent contact with the riverbed (bedmaterial load) (Church, 2006). The actual diameter of the the physical separation between washload and bed-material load may be different depending on streamflow conditions.

For the purposes of this report, the term "major tributaries" is assigned to streams that are tributary to the lower Missouri River, have streamgages with continuous periods of record spanning several decades, and are known to contribute substantial amounts of water and sediment to the lower Missouri River main stem. Under these criteria, the following tributaries were selected as "major tributaries" for the analyses described in this report: James River, Big Sioux River, Little Sioux River, Platte River (of Nebraska), Nishnabotna River, Nodaway River, Platte River (of Missouri), Kansas River, Grand River, Chariton River, Osage River, and Gasconade River (fig. 1).

Examination of spatial and temporal characteristics of SSC and PW in water year 2011 was focused on the period starting immediately before snowmelt and ice break up on the Great Plains, through the high-streamflow period and end of the water year (January 1 to September 30, 2011). Measurements of SSC made at the selected streamgages along the lower Missouri River were retrieved from the USGS National Water Information System (NWIS) (U.S. Geological Survey, 2012b).

Measurements taken on the same day, at the same streamgage, and using the same method were averaged to 
minimize bias. Stacked time-series plots and summary statistics were used to interpret and describe temporal and spatial characteristics of SSC. Measurements of PW were derived from the filtered set of SSC data by excluding samples that did not include measurement of the percentage of the suspendedsediment finer than $0.0625 \mathrm{~mm}$. USGS laboratory methods (Guy, 1969) provide two methods to measure the fraction of the suspended sediment that is finer than $0.0625 \mathrm{~mm}$ : (1) by physical sieving of the sediments, or (2) by visual-accumulation tube methods, which measure fractions according to the fall diameter of the sediments. In most cases, the available data for each day involved only one of these methods, but if both methods were used on a particular set of data for a single day, the result from the visual-accumulation tube method was chosen because it is a more precise measure (Hubbell and Stevens, 1986). Estimations of total annual SSD and average annual SSC for water year 2011 were characterized at the selected streamgages by longitudinal comparison of magnitudes and annual exceedance frequency during the period since completion of the MRMRS (1967 to 2011). Exceedance frequency was used instead of the observation rankings because the number of observations available at each mainstem streamgage within the period of record since closure of the MRMRS was not uniform. Annual exceedance frequency was estimated using the Cunnane (1978) plotting position formula as presented in Helsel and Hirsch (2002):

$$
F(i)=(i-0.4) /(n+0.2)
$$

where

$F(i) \quad$ is the exceedance frequency of observation $i$,

$i \quad$ is an observation, and

$n \quad$ is the total number of observations.

Estimations of total SSD and average annual SSC for water year 2011 were available in NWIS for all streamgages except Kansas City. Total SSD for water year 2011 was estimated for the Kansas City streamgage using the methods outlined in Heimann and others (2010). Records of annual total SSD for water years before 2011 were available for the selected streamgages from NWIS, Heimann and others (2010), and Heimann and others (2011).

\section{Suspended-Sediment Concentration}

Measured SSC in the lower Missouri River varied from approximately 150 milligrams per liter $(\mathrm{mg} / \mathrm{L})$ to $2,000 \mathrm{mg} / \mathrm{L}$ from January 1 through September 30, 2011 (fig. 2). Median SSC increased in the downstream direction from $355 \mathrm{mg} / \mathrm{L}$ at Sioux City to $490 \mathrm{mg} / \mathrm{L}$ at Hermann. The highest concentrations were measured downstream from Omaha in late February when snowmelt runoff from tributaries draining zones of high sediment production was entering the lower Missouri River, and releases of water from Gavins Point Dam were small. Variability in SSC, shown by the interquartile ranges of measured SSC (fig. 2), also increased in the downstream direction, except at Hermann.
From early March to late May, 2011, sediment concentrations were variable, and frequently exceeded the study-period median, as spikes in tributary runoff intermittently discharged along the length of the lower Missouri River. Measurements of SSC were most variable at Kansas City, where the effects of several upstream tributaries, notably the Platte (Missouri) and Kansas Rivers, caused SSC to vary from approximately $200 \mathrm{mg} / \mathrm{L}$ to $1,000 \mathrm{mg} / \mathrm{L}$ throughout the spring. Near the end of May, despite a spike in inflows from tributaries, measured $\mathrm{SSC}$ at all selected streamgages was lower than the intermittently high SSC observed during the winter and early spring. The lower magnitude of spikes in SSC likely was a result of a combination of progressive increases in the magnitude of clear-water releases at Gavins Point Dam as well as natural sediment-supply limitations on the landscape caused by vegetation and crop re-growth in late spring.

In late May, releases at Gavins Point Dam began to increase more rapidly and continued to increase until June 5 , when releases sharply increased, reaching approximately $150,000 \mathrm{ft}^{3} / \mathrm{s}$ by June 16, and 160,000 ft $3 / \mathrm{s}$ by June 26 (fig.

2). From early June through the end of September, releases at Gavins Point Dam constituted most of the streamflow observed at Hermann (fig. 2). The large magnitude increase in releases from Gavins Point Dam in early June caused small rises in SSC along the lower Missouri River, ranging from 300 to $600 \mathrm{mg} / \mathrm{L}$ above the station median (fig. 2). From mid-June through August 20, while releases at Gavins Point Dam were sustained at or above $150,000 \mathrm{ft}^{3} / \mathrm{s}$, measured SSC steadily decreased at all selected streamgages to levels between approximately 115 to $250 \mathrm{mg} / \mathrm{L}$ below observed station-median values. The combination of dilute releases at Gavins Point Dam, and stable, low-flows in tributaries caused sustained lowering of SSC at all streamgages from early July through late August, despite the high-magnitude streamflows along the main stem. SSC observations at most streamgages increased slightly and temporarily when releases at Gavins Point Dam began to decrease in late August, and again in midSeptember. The cause for the increase in SSC magnitude likely is either the reduced dilution of a base-level sediment concentration coming from tributaries, or enrichment with sediments from drainage and gullying of flooded areas along the valley bottom (Jacobson and Oberg, 1997).

\section{Washload}

Measured PW of suspended sediment ranged from 5 percent to as much as 98 percent in the lower Missouri River from January 1 to September 30, 2011 (fig. 3). Median $\mathrm{PW}$ increased in the downstream direction from 24 percent at Sioux City to 78 percent at Hermann. The total range of observed PW generally increased from upstream to downstream from 40 to 65 percent, but a large range of 59 percent also was observed at Nebraska City, where PW values likely were affected by sediment inputs from the Platte River of Nebraska. Measurements made in early January, when SSC was low, indicate that suspended sediment mostly was 


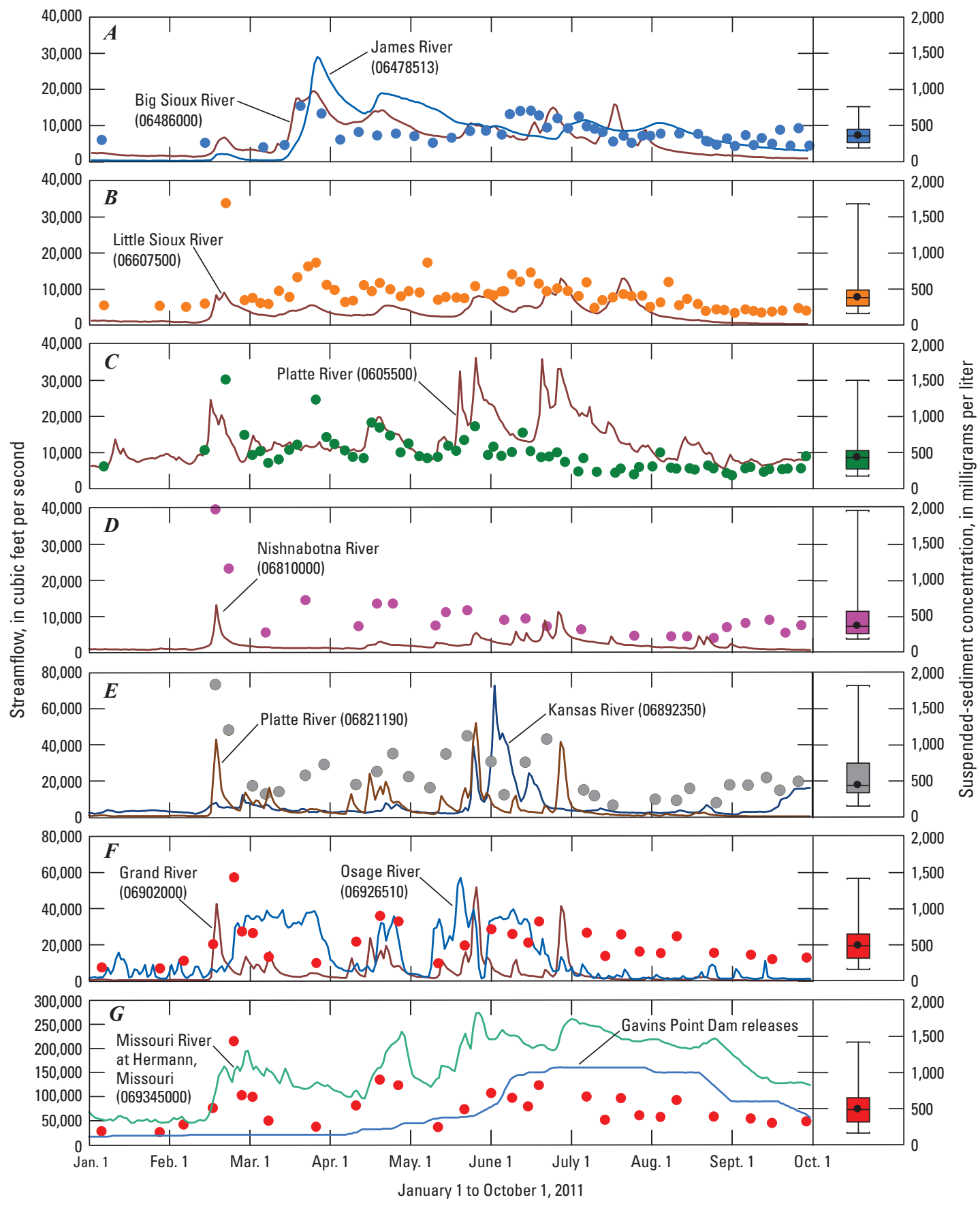

EXPLANATION
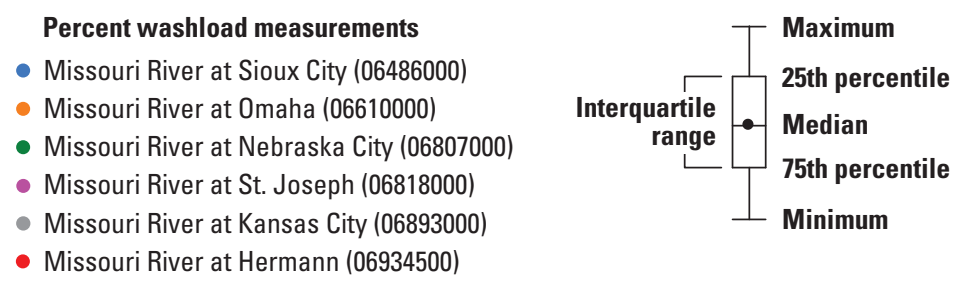

Figure 2. Frequency distribution of selected measurements of suspended-sediment concentration at streamgages along the lower Missouri River, and daily streamflow of major tributaries upstream from each measurement location, January 1 to October 1, 2011. Data for releases from Gavins Point Dam from U.S. Army Corps of Engineers. 
composed of bed material (PW ranged from 5 to 33 percent), although observations supporting this interpretation are limited. In mid-February, snowmelt runoff from the plains began to contribute streamflow to the lower Missouri River, and PW increased at most streamgages, ranging from 20 to 85 percent, indicating that early spring runoff was carrying mainly washload into the lower Missouri River. At Sioux City, PW increased only slightly through March, but spiked to a maximum observed value of 45 percent when runoff from the James River also spiked. Downstream from Nebraska City, increases in PW during snowmelt runoff were only observed at Hermann, but PW increased from a low of 33 percent in early January, to 80 percent by the end of February. Although no observations were made before snowmelt runoff at St. Joseph and Kansas City, both stations had high PW in late February, 78 and 85 percent respectively, and these values coincided with spikes in runoff from the Nishnabotna River and Platte River (of Missouri).

After spring runoff began, $\mathrm{PW}$ was variable at most stations, fluctuating in response to spikes in tributary streamflows as well as clear-water releases from Gavins Point Dam (fig. 3). Measured PW decreased by 16 to 55 percentage points as releases of water from Gavins Point Dam abruptly increased in early to mid-June, which coincided with more subtle decreases in SSC; however, after this initial decrease, observed levels of PW rebounded. This rebound of PW was most apparent in the observations at Omaha, Nebraska City, St. Joseph, and Kansas City, and likely was the result of finesediment inputs from the Big and Little Sioux Rivers and the Platte River (Nebraska). From late July through mid-August, decreases in PW ranging from 26 to 50 percentage points were observed at Omaha, Nebraska City, Kansas City, and Hermann, reflecting a reduction of tributary contributions, and the sustained high releases at Gavins Point Dam. After August 20, 2011, releases at Gavins Point Dam began to decrease, and observed levels of PW increased by 8 to 26 percentage points. The increase in PW likely was caused by a combination of decreased streamflow intensity reducing suspension of coarser bed material, as well as contributions of mud from drainage of adjacent flood plains.

\section{Suspended Load}

Total SSD at the selected streamgages in the lower Missouri River during water year 2011 ranged from approximately 29 million tons at Sioux City to 64 million tons at Kansas City (table 1). At Sioux City, total SSD for 2011 was the largest magnitude in the 33 years of published estimates. More than 630 miles downstream at Hermann, Mo., the total SSD was estimated at approximately 57 million tons, or nearly double the load estimated at Sioux City. Relative to the respective periods of record, total estimated SSD had the lowest exceedance frequencies (low exceedance frequency indicates an uncommon occurrence; a high exceedance frequency indicates a more common occurence) in the reaches between Gavins Point Dam and Nebraska City (2 to 21 percent), but increased substantially downstream ( 25 to 65 percent). Annual total SSDs with low exceedance frequencies were reported at Sioux City, Omaha, and Nebraska City in 2011 despite the moderateto-high exceedance frequencies for 2011 average SSC (38 to 84 percent), indicating that the duration of high-magnitude flooding, as opposed to SSC, was the primary driver of total SSD in 2011.

The dilute nature of the 2011 floodwater similarly is reflected in a longitudinal comparison of the exceedance frequencies of annual average streamflow and annual total SSD. Exceedance frequencies of annual average streamflow in 2011 in the lower Missouri River from Sioux City to Hermann were all approximately within the highest percentile of streamflow for the period of record (table 1). Despite the small exceedance frequencies of the 2011 average streamflow throughout the system, exceedance frequencies of total SSD increased from 2 percent at Sioux City to 65 percent at Hermann. Likewise, exceedance frequencies of annual average and annual peak streamflows in tributaries generally increased in the downstream direction, and those downstream from Nebraska City generally were high or very high, indicating that many tributaries were not contributing substantial amounts of additional water (or sediment) relative to a typical high-streamflow year on the lower Missouri River. The median exceedance frequency of 2011 annual average streamflow in tributaries between Gavins Point Dam and Nebraska City was 5 percent, and ranged from 2 to 11 percent; median annual peak streamflow exceedance frequency was 34 percent, and ranged from 2 to 55 percent. Downstream from Nebraska City, the 2011 annual average streamflow in tributaries had a median exceedance frequency of 34 percent, and ranged from 15 to 64 percent; annual peak streamflow of these tributaries had a median exceedance frequency of 39 percent, and ranged from 5 to 59 percent.

Although annual total SSD approximately doubled from Sioux City to Hermann, substantial along-stream variation indicates incongruities in the net sediment balance. Between Nebraska City and St. Joseph, total SSD for 2011 decreased by approximately 7.5 million tons, indicating net sediment deposition between streamgages. Such deposition is feasible between these streamgages because, as indicated in a subsequent section of this report (see "Patterns of Sediment Deposition Along the Lower Missouri River during the Flood of 2011"), the segment of the lower Missouri River between Omaha and St. Joseph was a zone of substantial overbank flooding and sand deposition. Although the area of the lower Missouri River upstream from Omaha also was a zone of substantial overbank streamflow and sediment deposition, the influx of sediment from the Little Sioux and Platte Rivers likely contributed to the net increase in sediment discharge between the Sioux City and Nebraska City streamgages. An increase in total SSD of nearly 30 million tons was estimated between St. Joseph and Kansas City. Although such an increase is substantial, data from Heimann and others (2010) indicate that the Kansas River may contribute more than 20 million tons of suspended sediment to the lower 

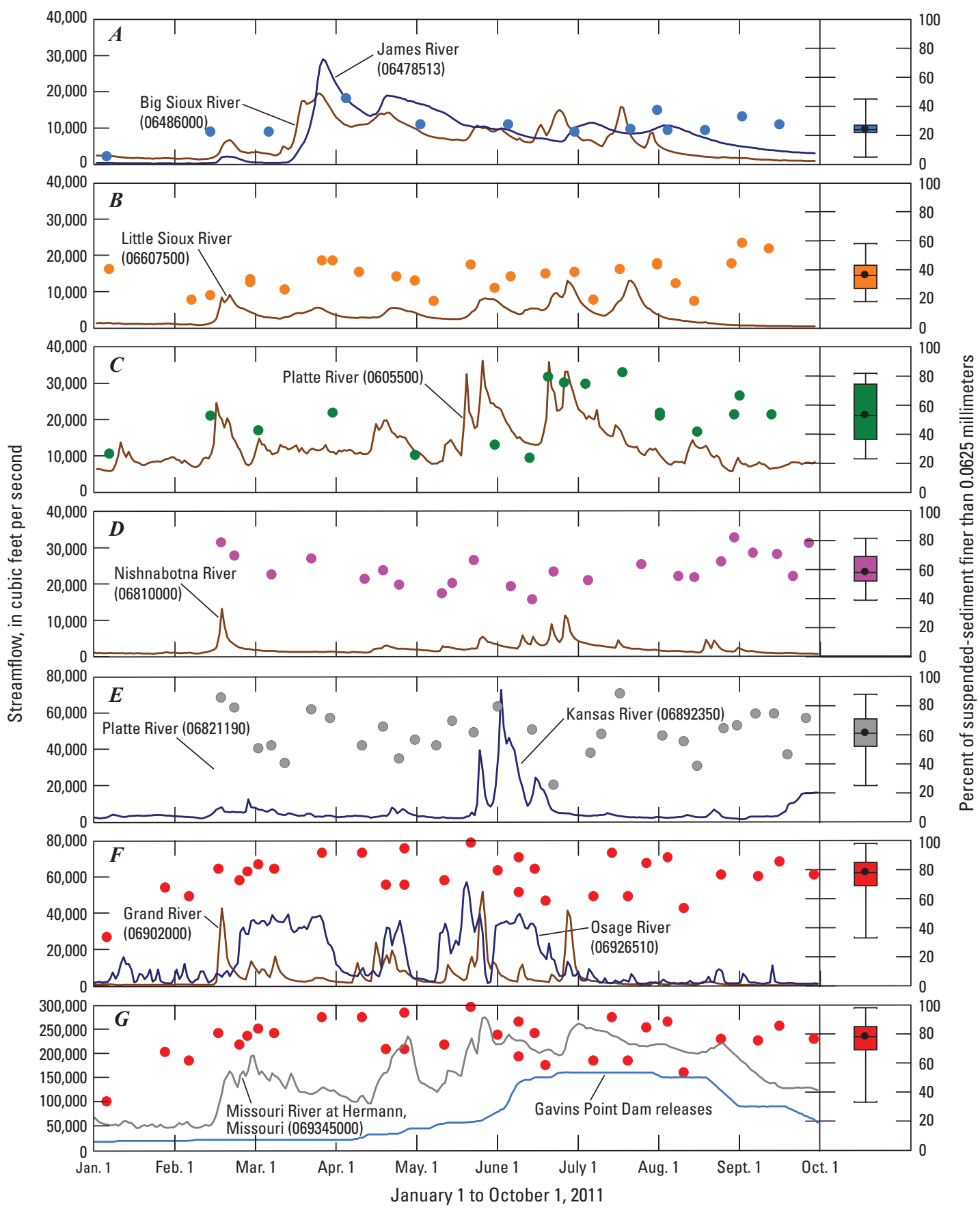

EXPLANATION
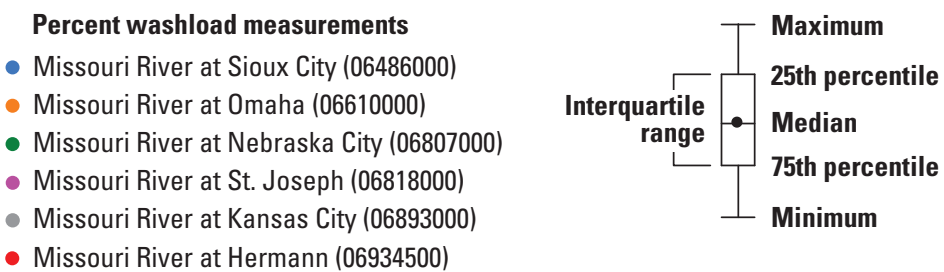

Figure 3. Frequency distribution of measured percentage of suspended-sediment as washload (percentage of suspended-sediment mixture finer than 0.0625 millimeter in diameter) at selected streamgages along the lower Missouri River and daily streamflows of major tributaries upstream from each measurement location, January 1 to October 1, 2011. Data for releases from Gavins Point Dam from U.S. Army Corps of Engineers. 
Missouri River when its annual instantaneous peak streamflow approaches $80,000 \mathrm{ft}^{3} / \mathrm{s}$. Thus, such an increase in total SSD is feasible for the St. Joseph-to-Kansas City reach and within the confidence bounds of previous annual estimates of total SSD for the Kansas River (Heimann and others, 2010). Between Kansas City and Hermann, total SSD in the lower Missouri River in 2011 decreased by approximately 6.5 million tons, and this decrease likely was due to a combination of deposition between streamgages (either on low-lying regions of the flood plain or aggradation on the riverbed), uncertainties in the total SSD estimation at Kansas City, or both.

\section{Comparison of Sediment Transport in 2011 with Other Recent Floods}

The geography of tributaries contributing to flooding in a large river system is important to the understanding of sediment transport and deposition, because spatial variations in geology and climate affect the texture and erodibility of soils, and infrastructure, such as dams, channel engineering, and levees, may affect sediment routing through a river network (Schmidt and Wilcock, 2008; Meade and Moody, 2010). One of the primary goals of the study described in this report was to place the characteristics of sediment transport during the flood of 2011 in the context of previous floods, and of particular interest were floods with differing floodwater geography. Sediment transport in the lower Missouri River in 2011 was contextualized using two primary approaches: (1) comparison of SSC at selected locations with the recent period of record, and (2) comparison of floodwater geography and total SSD with two other recent floods in the lower Missouri River, 1993 and 2008 .

Comparison of sediment transport in the lower Missouri River during 2011 with other periods in the available period of record requires precaution because streamflow-adjusted sediment loads decreased abruptly after the construction of the MRMRS (Meade and Moody, 2010; Heimann and others, 2011), and have been progressively decreasing during the past three decades (Heimann and others, 2010). Thus, to reduce the trend effect of declines in magnitude of streamflow-weighted SSC, only the 20-year period of record preceding water year 2011 was selected for comparison (hereinafter referred to as "the selected period of record"). Suspended-sediment concentrations in 2011 and for the selected period of record were divided into two primary groups for comparison within ranges of streamflow magnitude concurrent with SSC sampling. High-action streamflows (group 1) were defined as flows that would be likely to generate a river stage that exceeded the National Weather Service's (NWS) “action stage." In 2011, the NWS action stage was between 2 and $4 \mathrm{ft}$ below the NWS "flood stage" at the selected streamgages, and represents a trigger point at which flood mitigation and preparations begin (http://w1.weather.gov/glossary/index, accessed December 12, 2012). Low-action streamflows (group 2) were defined as streamflows less than those producing the NWS action stage. Suspended-sediment concentration measurements and SSD records for the Sioux City, Omaha, and Nebraska City streamgages were retrieved from NWIS (http://waterdata. usgs.gov/nwis, accessed December 12, 2012). Suspendedsediment concentration measurements and SSD records for the St. Joseph, Kansas City, and Hermann streamgages were taken from Heimann and others (2011) and Heimann and others (2010) for the period of record before water year 2009, and retrieved from NWIS for water years 2010 and 2011. Examination of streamflow measurements from the 1991 to 2011 water years indicated that, within an approximate 10-percent margin, a streamflow of approximately $70,000 \mathrm{ft}^{3} / \mathrm{s}$ would be likely to trigger the NWS action stage at the Sioux City, Omaha, Nebraska City, and St. Joseph streamgages, and a streamflow of approximately $150,000 \mathrm{ft}^{3} / \mathrm{s}$ would potentially trigger the NWS action stage at the Kansas City and Hermann streamgages. These estimates were conservative by design because the streambed elevation at several streamgages has changed during the past several decades, precluding the identification of a single, temporally stable streamflow value corresponding to an action stage. After SSC data were categorized, a nonparametric multiple-comparison test (Tukey distribution, alpha $=0.05$; Helsel and Hirsh, 2002; Lorenz and others, 2011) was conducted on the data ranks to test for statistical significance of differences in median SSC among the four data groups: (1) low-action streamflows, 1991-2010; (2) high-action streamflows, 1991-2010; (3) low-action streamflows, 2011; and (4) high-action streamflows, 2011. To reduce the magnitude of imbalance in sample sizes between groups, any group with a sample size greater than 3 times larger than the largest sample size from its corresponding 2011 group was reduced using a subsampling procedure that reduced that sample size to 30 based on the quantiles of the distribution (see Helsel and Hirsh, 2002, p. 44).

Total suspended sediment discharge in the lower Missouri River during water years 1993 and 2008 were chosen for direct comparison with SSD for 2011. These two years were chosen because the geography of floodwaters were well documented (Parrett and others, 1993; Holmes, 1996; Holmes and others, 2010), the geographies of floodwater differ from those of 2011, and 1993 and 2008 annual average and annual peak streamflows at the selected streamgages differed from those in 2011. In contrast to 2011, floodwater in the lower Missouri River in 1993 and 2008 originated primarily downstream from the MRMRS (Wahl and others, 1993; Holmes and others,

2010). Floodwater geography was characterized for each water year by examining the percent contribution of tributaries to the annual average streamflow of the lower Missouri River at Hermann. Longitudinal differences in total SSD in the lower Missouri River were examined by comparison of the exceedance frequencies of annual average and annual peak streamflows at the selected main-stem streamgages and streamgages in major tributaries. Exceedance frequencies for annual average and annual peak streamflows were calculated using equation 1. Annual average and annual peak streamflow records were retrieved from NWIS for the selected main-stem and 
Table 1. Magnitude and exceedance frequency of annual average and peak streamflows, annual average suspended-sediment concentration, and annual total suspendedsediment discharge for selected main-stem and tributary streamgages, lower Missouri River, water year 2011.

[USGS, U.S. Geological Survey; No., number; n, number of observations in record up to and including water year 2011; fts, cubic feet per second; Exc. Freq., estimated exceedance frequency; USACE, U.S. Army Corps of Engineers; \%, percentage of years within indicated period of record that a magnitude was equaled or exceeded. A larger percentage indicates a more common magnitude, a smaller percentage indicates less common magnitude; conc., concentration; $\mathrm{mg} / \mathrm{L}$, milligrams per liter; --, data not available; total suspended-sediment discharge, total mass of sediment passing a measurement point in units shown]

\begin{tabular}{|c|c|c|c|c|c|c|c|c|c|c|c|c|c|c|}
\hline \multirow{2}{*}{$\begin{array}{c}\text { USGS } \\
\text { station } \\
\text { number }\end{array}$} & \multirow[t]{2}{*}{ Station name } & \multirow[t]{2}{*}{ Location ${ }^{\mathrm{b}}$} & \multicolumn{3}{|c|}{ Annual average streamflow } & \multicolumn{3}{|c|}{ Annual peak streamflow } & \multicolumn{3}{|c|}{$\begin{array}{c}\text { Annual average } \\
\text { suspended-sediment } \\
\text { concentration }^{\mathrm{d}}\end{array}$} & \multicolumn{3}{|c|}{$\begin{array}{l}\text { Annual total suspended- } \\
\text { sediment sediment } \\
\text { concentration }^{\mathrm{d}}\end{array}$} \\
\hline & & & $\mathbf{n}$ & $\begin{array}{l}\text { Flow } \\
\left(\mathrm{ft}^{3} / \mathrm{s}\right)\end{array}$ & $\begin{array}{c}\text { Exc. freq. }^{\mathrm{c}} \\
(\%)\end{array}$ & $\mathbf{n}$ & $\begin{array}{l}\text { Flow } \\
\left(\mathrm{ft}^{3} / \mathrm{s}\right)\end{array}$ & $\begin{array}{c}\text { Exc. freq. } \\
(\%)\end{array}$ & $\mathbf{n}$ & $\begin{array}{l}\text { Conc. } \\
\text { (mg/L) }\end{array}$ & $\begin{array}{c}\text { Exc. freq. }^{\mathrm{c}} \\
(\%)\end{array}$ & $\mathbf{n}$ & $\begin{array}{l}\text { Conc. } \\
\text { (mg/L) }\end{array}$ & $\begin{array}{c}\text { Exc. } \\
\text { freq }(\%)\end{array}$ \\
\hline USACE $^{\mathrm{e}}$ & Gavins Point Dam & 811.1 & 45 & 65,600 & 1 & 45 & 160,700 & 1 & -- & -- & -- & -- & -- & -- \\
\hline $06478513^{\mathrm{f}}$ & James River near Scotland, South Dakota & 800.6 & 83 & 5,800 & 2 & 83 & 28,400 & 2 & -- & -- & -- & -- & -- & -- \\
\hline 06485500 & Big Sioux at Akron, Iowa & 734.5 & 83 & 5,800 & 2 & 83 & 19,700 & 28 & -- & -- & -- & -- & -- & -- \\
\hline 06486000 & Missouri River at Sioux City, Iowa & 732.4 & 45 & 79,100 & 1 & 45 & 192,000 & 1 & 33 & 330 & 38 & 33 & $28,600,000$ & 2 \\
\hline 06607500 & Little Sioux River near Turin, Iowa & 668.9 & 53 & 3,300 & 9 & 72 & 13,400 & 40 & -- & & & & & \\
\hline 06610000 & Missouri River at Omaha, Nebraska & 616.0 & 45 & 86,400 & 1 & 45 & 217,000 & 1 & 45 & 440 & 84 & 40 & $32,560,000$ & 80 \\
\hline 06805500 & Platte River at Louisville, Nebraska & 595.5 & 58 & 11,500 & 11 & 59 & 45,400 & 55 & -- & & & & & \\
\hline 06807000 & $\begin{array}{l}\text { Missouri River at Nebraska City, } \\
\text { Nebraska }\end{array}$ & 562.6 & 45 & 96,700 & 1 & 45 & 229,000 & 1 & 40 & 440 & 84 & 40 & $40,370,000$ & 21 \\
\hline 06810000 & Nishnabotna River at Hamburg, Iowa & 543.3 & 84 & 2,000 & 15 & 85 & 16,800 & 49 & -- & -- & -- & -- & -- & -- \\
\hline 06817000 & Nodaway River at Clarinda, Iowa & 462.7 & 78 & 560 & 24 & 84 & 30,000 & 5 & -- & -- & -- & -- & -- & -- \\
\hline 06818000 & Missouri River at St. Joseph, Missouri & 448.2 & 45 & 104,500 & 1 & 45 & 277,000 & 4 & 45 & 380 & 96 & 45 & $32,700,000$ & 63 \\
\hline 06821190 & Platte River at Sharps Station, Missouri & 391.0 & 32 & 1,300 & 64 & 33 & 14,900 & 59 & -- & -- & -- & -- & -- & -- \\
\hline 06892350 & Kansas River at DeSoto, Kansas & 367.2 & 94 & 5,600 & 58 & 38 & 80,200 & 23 & -- & -- & -- & -- & -- & -- \\
\hline 06893000 & Missouri River at Kansas City, Missouri & 366.1 & 45 & 109,300 & 1 & 45 & 245,000 & 12 & 38 & 590 & 83 & 38 & $63,600,000$ & 25 \\
\hline 06902000 & Grand River near Sumner, Missouri & 250.2 & 87 & 3,800 & 52 & 91 & 53,000 & 59 & -- & -- & -- & -- & -- & -- \\
\hline 06905500 & Chariton River near Prarie Hill, Missouri & 239.0 & 82 & 1,800 & 25 & 83 & 22,900 & 28 & -- & -- & -- & -- & -- & -- \\
\hline $06926510^{\mathrm{g}}$ & Osage River below St. Thomas, Missouri & 130.4 & 80 & 10,400 & 51 & 80 & 58,600 & 54 & -- & -- & -- & -- & -- & -- \\
\hline 06933500 & Gasconade River at Jerome, Missouri & 104.9 & 89 & 3,700 & 19 & 93 & 85,100 & 8 & -- & -- & -- & -- & -- & -- \\
\hline 06934500 & Missouri River at Hermann, Missouri & 97.9 & 45 & 139,200 & 8 & 45 & 279,000 & 63 & 45 & 340 & 92 & 45 & $57,000,000$ & 65 \\
\hline
\end{tabular}

${ }^{\mathrm{a}}$ For most stations this is the streamgage nearest the confluence with the Missouri River main channel (most downstream streamgage).

${ }^{b}$ Distance in miles upstream from the confluence with the Mississippi River, based on unpublished data from U.S. Army Corps of Engineers.

${ }^{\mathrm{c}}$ Calculated using Cunane (1978) plotting position formula.

dData shown for, at most, 1967 to 2011, the period after completion of the Missouri River Mainstem Reservoir System.

eData provided by Dan Pridal (U.S. Army Corps of Engineers, written commun., 2012).

fStation used has longest period of record but is not station nearest confluence with Missouri River.

gValues from station combined with nearby discontinued station (06926500) to create longer period of record.

hValue calculated using methods of Heimann and others (2010) and Dave Heimann (U.S. Geological Survey, written commun., 2012). 
tributary streamgages. For tributaries, with the exception of the James and Osage Rivers, the annual average and annual peak streamflow records for the entire period of record were selected and data for the most downstream streamgage were used. In the case of the James River, a streamgage near the mouth of the watershed (the James River at Scotland, S. Dak., USGS station no. 06478500, not shown on fig. 1) was used instead of the most downstream gage (the James River near Yankton, S. Dak., USGS station no. 06478513) because it had a much longer and continuous period of record. In the case of the Osage River, the annual average and annual peak streamflow records from two streamgages (the Osage River near St. Thomas, Mo., USGS Station no. 06926500, not shown on fig. 1, and the Osage River below St. Thomas, USGS Station no. 06926510) were combined because the two gages were near each other, and their combined periods of record did not overlap, but created an unbroken period of record from 1931 to 2011. For Missouri River main-stem gages, only exceedance frequencies for the period from 1967 to 2011 were examined because of the pronounced change in hydrology associated with completion of the MRMRS in 1967.

Median values of SSC from samples at selected streamgages along the lower Missouri River from 1991 to 2010 indicate that SSC generally increased from upstream to downstream during low-action and high-action streamflow conditions. Median values of SSC for samples taken during low-action flows ranged from a low of approximately 190 $\mathrm{mg} / \mathrm{L}$ at Sioux City to a high of $490 \mathrm{mg} / \mathrm{L}$ at Kansas City, but decreased to $290 \mathrm{mg} / \mathrm{L}$ at Hermann (fig. 4). Similarly, median SSC for samples taken during high-action streamflows ranged from a low of approximately $530 \mathrm{mg} / \mathrm{L}$ at Sioux City to $1,340 \mathrm{mg} / \mathrm{L}$ at Kansas City but decreased to approximately $1,120 \mathrm{mg} / \mathrm{L}$ at Hermann. Decreases in median sample SSC values at Hermann likely are associated with contributions of large volumes of more dilute water from the Ozark Plateaus by the Gasconade River and highly impounded Osage River, which flow into the lower Missouri River just upstream from Hermann. Differences between median values of SSC for samples taken during high-action streamflows and those taken during low-action streamflows for the selected period of record ranged from approximately 350 to $850 \mathrm{mg} / \mathrm{L}$ among the selected sites, and the interquartile ranges of the two sample groups show little (2 sites) to no distributional overlap (4 sites; fig. 4), indicating that differences in sample SSC between the two streamflow conditions likely are distinct. A multiplecomparison analysis indicated that the differences in sample median SSC between high-action and low-action streamflows for the selected period of record are significant statistically ( $p$-values less than 0.001) for all streamgages where such analysis was considered valid (fig. 4).

Median values of SSC for samples during high-action streamflows in 2011 were greater than the median values for samples during low-action streamflows in 2011 for a few of the selected streamgages, and statistically significant differences in median values for both streamflow conditions were only detected at Hermann ( $p$-value $<0.01$ ) (fig. 4), but median
SSC for both streamflow conditions consistently were lower than the median values for high-action streamflows during the 20 years before. Similar to the 20 years before, median sampled SSC in 2011 during low-action streamflows generally increased from Sioux City to Kansas City, then decreased between Kansas City and Hermann; the spatial pattern for median sampled SSC in 2011 during high-action streamflows was not consistent with the 20 years before, showing decreases between Nebraska City and Kansas City, and increases between Kansas City and Hermann. Median SSC during low-action streamflows in the lower Missouri River in 2011 ranged from a low of approximately $270 \mathrm{mg} / \mathrm{L}$ at Sioux City to a high of $460 \mathrm{mg} / \mathrm{L}$ at Kansas City. Median SSC during high-action streamflows ranged from a low of $380 \mathrm{mg} / \mathrm{L}$ at Sioux City to a high of $620 \mathrm{mg} / \mathrm{L}$ at Hermann (fig. 4). Differences between median values of SSC for low- and high-action streamflows at the selected streamgages in 2011 were small relative to the corresponding differences between the same streamflow groups for the 20 years before, ranging only from 130 to $350 \mathrm{mg} / \mathrm{L}$ among the selected streamgages in 2011 .

The signature of reservoir decanting on SSC in the lower Missouri River in 2011 was evident in the contrasting frequency distributions of SSC for low- and high-action streamflows at the selected monitoring stations. Simple differences between median SSC for low- and high-action streamflows in 2011, when compared with the corresponding differences for the selected period of record, indicate that median SSC values for 2011 are, in most cases, closer to the median values for low-action streamflows for the 20 years before. Differences between median SSC for samples during high-action streamflows in 2011 and those for the selected period of record ranged from approximately $170 \mathrm{mg} / \mathrm{L}$ to $1,010 \mathrm{mg} / \mathrm{L}$, whereas differences between high-action streamflow samples from 2011 and samples during low-action streamflows for the selected period of record ranged from approximately $0 \mathrm{mg} / \mathrm{L}$ to $340 \mathrm{mg} / \mathrm{L}$. Multiple-comparison analysis indicated that median SSC values for low- and high-action streamflows sampled in 2011 at 4 of 6 monitoring stations were not significantly distinguishable from median SSC values for low-action streamflows during the select period of record (fig. 4). Similarly, multiple-comparison analysis indicated that median SSC for high-action streamflows sampled in 2011 were not significantly distinguishable from those of low-action streamflows sampled in 2011 at 4 of 5 streamgages where such analysis was considered valid.

During the 20-year period of record preceding water year 2011, the annual average streamflow of the lower Missouri River at Hermann, Mo., was 94,200 $\mathrm{ft}^{3} / \mathrm{s}$. On average, the largest contributions to the annual streamflow at Hermann are from major tributaries originating in the high sedimentproduction areas of the Great Plains and Central Lowland (37 percent), releases of water through Gavins Point Dam (28 percent), and small tributaries plus groundwater inflows (hereinafter referred to collectively as "small tributaries") (19 percent) (fig. 5). In 2011, the annual average streamflow of the lower Missouri River at Hermann was 139,200 $\mathrm{ft}^{3} / \mathrm{s}$; the 
sustained, very large releases of water through Gavins Point Dam constituted approximately 47 percent of this streamflow, but no tributary downstream from the dam contributed more than 10 percent, and small tributary contributions accounted for only 13 percent. By contrast, in 1993 and 2008, years when heavy rains were concentrated in the downstream regions of the Missouri River Basin (Wahl and others, 1993; Holmes and others, 2010), releases of water from Gavins Point Dam accounted for only 7 and 12 percent, respectively, of the annual average streamflow at Hermann, reflecting the operation of the MRMRS for downstream flood control. Small tributary contributions accounted for approximately 25 percent of the average annual streamflow at Hermann in 2008 and 1993, and major tributaries flowing through regions with high sediment production accounted for approximately 50 percent of the annual average streamflow at Hermann in 1993, and 40 percent in 2008 (fig. 5). In 2011, major tributaries in high sediment-production regions accounted for a total of only 28 percent of the average annual streamflow in the lower Missouri River at Hermann.

Longitudinal comparison of streamflow and annual total sediment-discharge exceedance frequencies for the lower Missouri River in 2011 with corresponding frequencies for 2008 and 1993 showed the important role of tributary contributions to total SSD of the lower Missouri River and the effect of clear-water releases on total SSD in 2011. Annual streamflow exceedance frequencies at the selected main-stem streamgages decreased from 74 percent at Sioux City to 1 percent at Hermann in 1993, and from 99 percent to 26 percent in 2008. Likewise, annual peak-streamflow exceedance frequencies at the selected main-stem streamgages in 1993 decreased from 19 percent at Sioux City to 1 percent at Hermann, and from 77 percent to 26 percent in 2008. Much of the downstream increase in streamflow in 1993 and 2008 was a consequence of heavy rains falling on saturated soils in watersheds of the
Great Plains and Central Lowlands (Wahl and others, 1993; Holmes and others, 2010), producing streamflows of large magnitude and long duration in major tributaries to the lower Missouri River. These contributions are reflected in low exceedance frequencies of annual average and peak streamflows for major tributaries. In 1993, exceedance frequencies of annual average and peak streamflows in major tributaries were almost uniformly within the upper decile of streamflows for their respective periods of record (fig. 6), and annual average streamflows in 10 of 12 major tributaries were within the top 3 percent. In 2008, tributary contributions were also important to the pattern of streamwise-decreasing exceedance frequencies of annual average streamflow along the lower Missouri River. Annual average and annual peak streamflows for 2008 in the Platte (Nebraska), Nishnabotna, Nodaway, Platte (Missouri), Grand, Chariton, and Gasconade Rivers all had exceedance frequencies approximately within the upper quartile of streamflows for their respective periods of record ending in 2011; annual peak streamflows in the Nodaway and Chariton Rivers were the highest on record.

In contrast with 1993 and 2008, exceedance frequencies of annual average and peak streamflows at the selected streamgages in 2011 increased from upstream to downstream. Exceedance frequencies of annual average streamflow in 2011 were in the upper 1 percent during the post-dam period of record from Sioux City to Kansas City, and was 8 percent at Hermann. However, exceedance frequencies of instantaneous peak streamflows were in the highest-streamflow percentile during the post-dam period of record at Sioux City, Omaha, and Nebraska City, but exceedance frequency then increased to 12 percent by Kansas City and 63 percent at Hermann. The pattern of downstream increasing exceedance frequencies for streamflow highlights the effect of the lack of synchrony between reservoir-release flows and variable inflows from downstream tributaries in 2011. Exceedance frequencies of

\section{Langdon backwater on the Missouri River near Nemaha, Nebraska, looking upstream from the mouth, October 24, 2011. Photograph by Justin Krahulik, U.S. Geological Survey.}




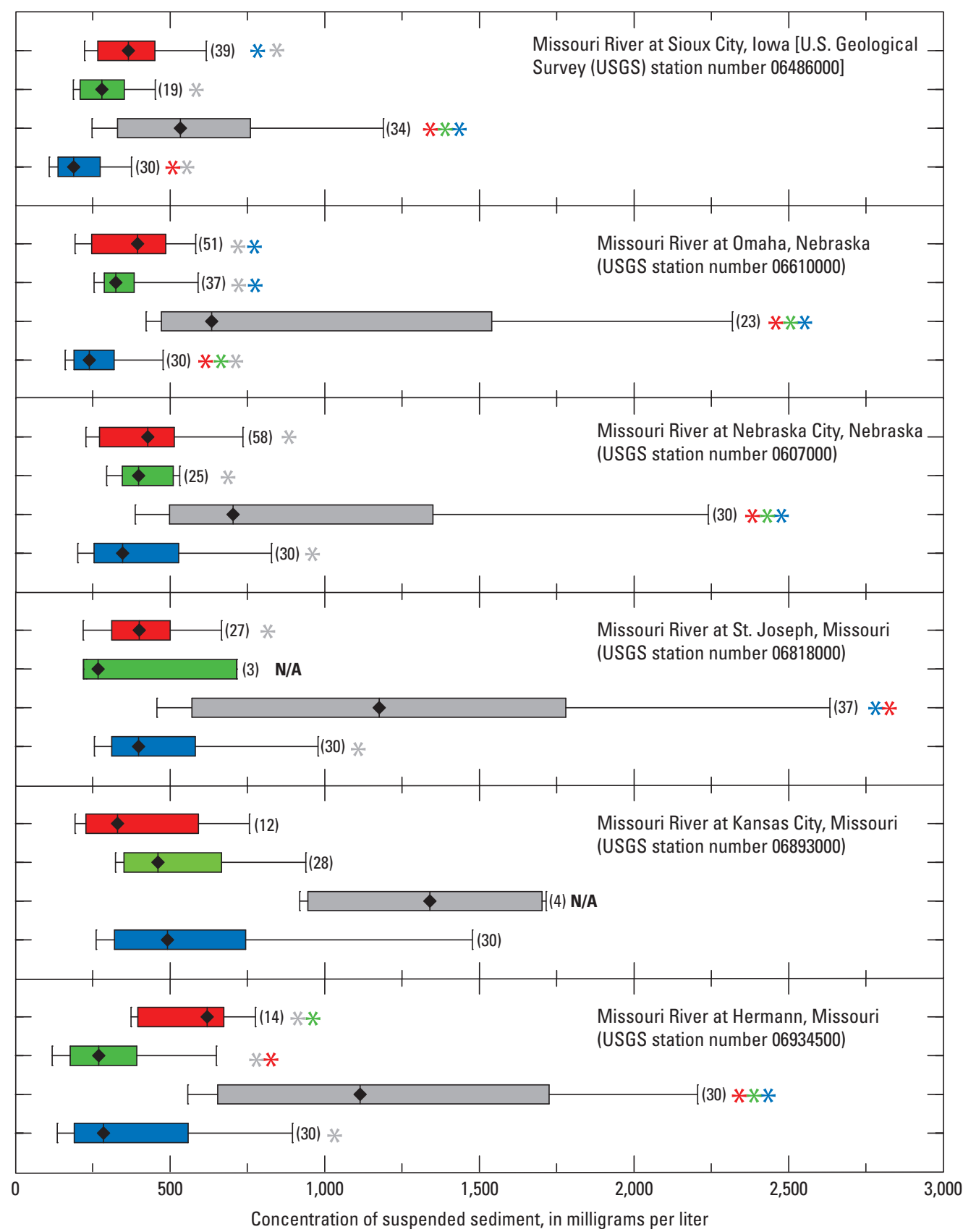

EXPLANATION

Water year 2011-Samples taken at high-action streamflows

Water year 2011-Samples taken at low-action streamflows

Water years 1991 to 2010—Samples taken at high-action streamflows

Water years 1991 to 2010—Samples taken at low-action streamflows

$* * * *$ Median of distribution is significantly different than distribution of category with indicated color (based on nonparametric multiple-comparison analysis at 95-percent confidence level)

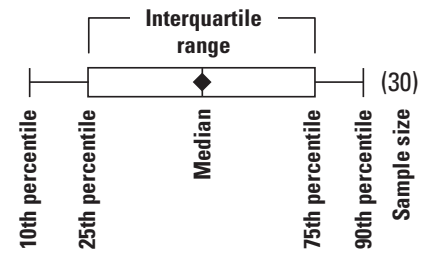

N/A Indicates statistical test not considered valid because of small sample size

Figure 4. Frequency distributions of sampled suspended-sediment concentrations for selected streamgages along the lower Missouri River for low- and high-action streamflows in water year 2011, and in the preceding 20 water years. High-action streamflows are defined as streamflows likely to trigger the National Weather Service action stage. Low-action streamflows are defined as streamflows likely to produce stages less than the National Weather Service action stage. 
A. 1993 annual average flow $=182,000 \mathrm{ft}^{3} / \mathrm{s}$

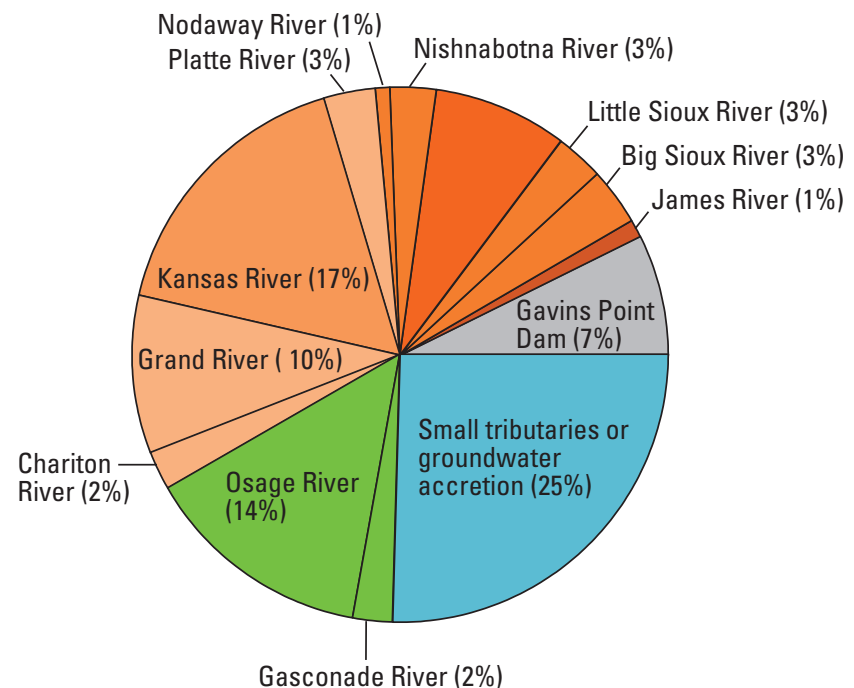

C. 2011 annual average flow $=139,200 \mathrm{ft}^{3} / \mathrm{s}$

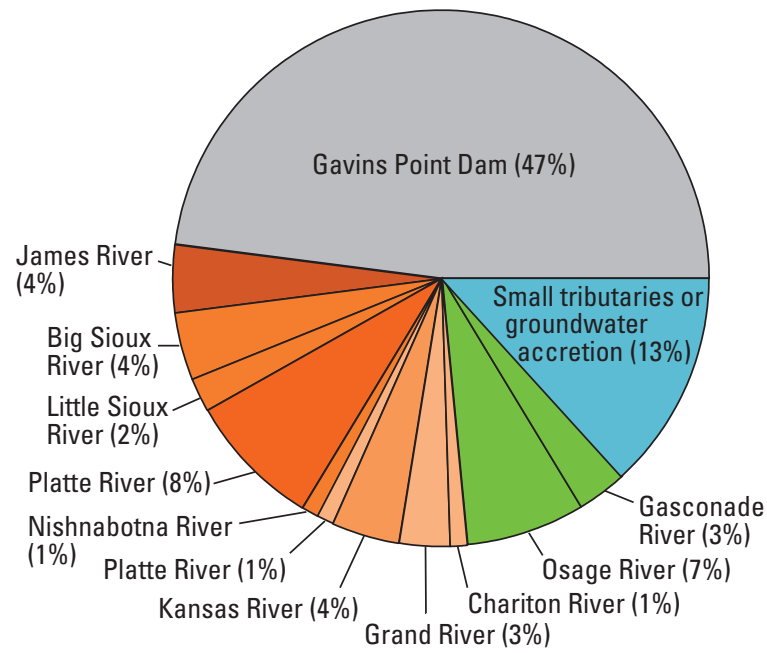

B. 2008 annual average flow $=115,000 \mathrm{ft}^{3} / \mathrm{s}$

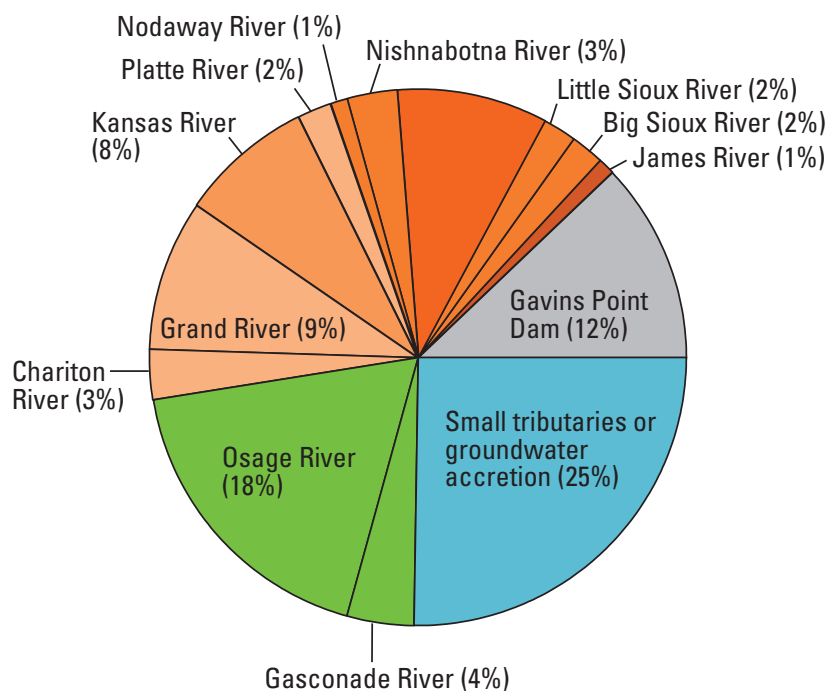

D. 1991-2010 annual average flow $=94,200 \mathrm{ft}^{3} / \mathrm{s}$

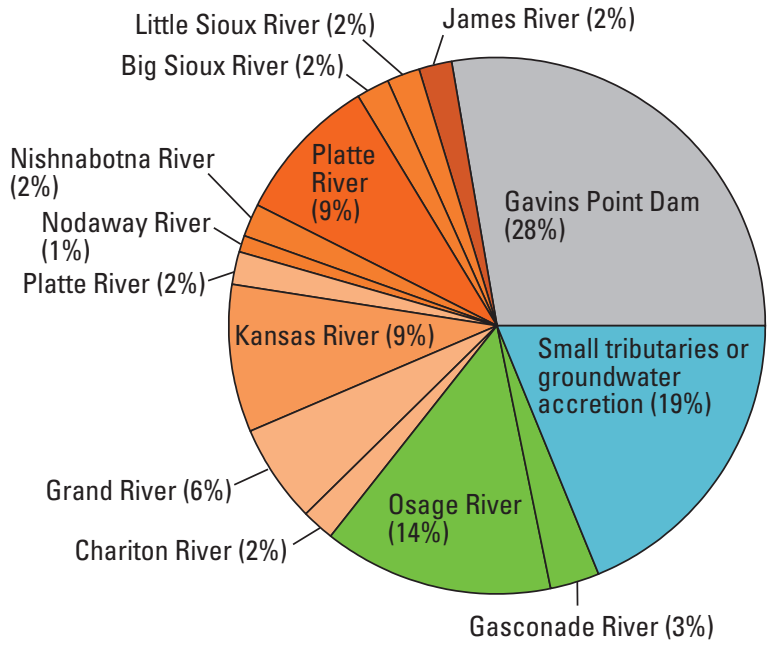

EXPLANATION

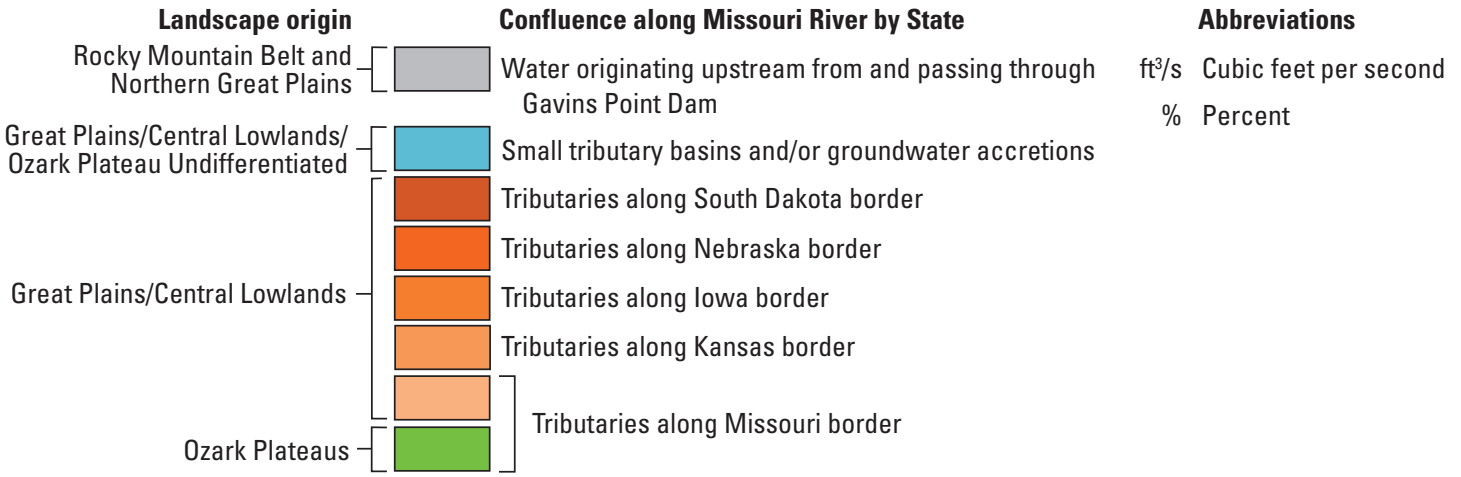

Figure 5. Relative contributions of tributary streamflow to annual average streamflow of the Missouri River at Hermann, Missouri (U.S. Geological Survey streamgage number 06934500), during water years 1993, 2008, and 2011, and average for the 20-year period-of-record preceding water year 2011, as percentage of total. Data shown for individual tributary basins are represented by most downstream streamgage on each tributary. Actual contributions may be different than shown. 
annual average streamflows in tributaries draining snowmelt from mountains or northern Great Plains regions such as the James, Big Sioux, Little Sioux, and Platte Rivers ranged from 2 percent to 11 percent for the respective periods of record, but increased substantially in major tributaries downstream from the confluence of the Platte River (Nebraska), ranging from 15 to 64 percent (fig. 6). Potentially more important to sediment transport, exceedance frequencies of annual peak streamflows in major tributaries to the lower Missouri River were generally low in 2011, but 6 of 12 tributaries had exceedance frequencies of 40 percent or greater, and 4 had frequencies greater than 50 percent.

Differences between relative streamflow contributions from Gavins Point Dam releases and downstream tributaries in 1993, 2008, and 2011 translated into real differences in the magnitude of total SSD along the lower Missouri River. In 1993 and 2008, the combination of smaller dam releases and greater downstream tributary contributions resulted in a 20-fold increase in annual total SSD from Sioux City to Hermann. In 2011, record releases at Gavins Point Dam were paired with tributary contributions that, although large between Gavins Point Dam and the Platte River (Nebraska), were less consequential downstream from there, and annual total SSD at Hermann was only twice that estimated for Sioux City. In 1993 and 2008, total SSD at Hermann was approximately 177 million tons and 89 million tons, respectively, and annual average streamflow was $182,800 \mathrm{ft}^{3} / \mathrm{s}$ and $114,600 \mathrm{ft}^{3} / \mathrm{s}$, respectively. In 2011, annual total SSD was approximately 57 million tons, and annual average streamflow at Hermann was $139,200 \mathrm{ft}^{3} / \mathrm{s}$. Thus, in 1993, the lower Missouri River discharged 300 percent more suspended sediment with an average streamflow that was only 30 percent larger than in 2011, and in 2008 transported 50 percent more suspended-sediment with an annual average streamflow that was 20 percent lower than in 2011. Despite the much larger overall total sediment load of the 1993 flood relative to the 2008 and 2011 floods, Holmes (1996) indicated that the 1993 flood transported less sediment on a per-day basis than did other large floods in 1973 and 1951. Thus, the comparisions reported herein further indicate declines in suspended-sediment transport of the Missouri River relative to its pre-development condition.

\section{Patterns of Sediment Deposition Along the Lower Missouri River during the Flood of 2011}

The purpose of estimating sand deposition along the flood plain of the lower Missouri River was to assess sediment-related geomorphic effects and damages. Sand deposition was estimated using analysis of multispectral satellite imagery collected in October and November 2011. Twenty-six 10- or 20-meter resolution multispectral images obtained by the Système Pour l'Observation de la Terre (SPOT)-4 or -5 satellites (data available from the U.S. Geological SurveyEarth Resources Observation and Science Center) provided coverage of the entire 811 miles of the lower Missouri River when streamflows were entirely within the riverbanks. Sand was mapped using a supervised classification of image pixels (fig. 7), and confirmed by field visits. Exposed sand within the banks (sandbars) was excluded from the analysis. Computation of areal extent of sand deposits provides a conservative estimate of sand deposition because sand overlain by mud is excluded, and sand deposits are undermapped in wooded areas. Neither volume nor mass of sand was estimated; however, a similar analysis of deposition on the Mississippi River flood plain after the 1993 flood indicated that minimum detectable thickness of sand deposits was approximately $2 \mathrm{ft}$ (Jacobson and Oberg, 1997).

The distributions of sand deposits along the flood plain of the lower Missouri River also were analyzed in relation to distance from the banks of the main channel by summing the area of sand within progressively wider buffer-distance swaths calculated using digital map analysis software (ESRI, 2010). Sand deposition accounting was subtotaled for seven discrete hydrologic segments, bounded by Gavins Point Dam and subsequent downstream tributaries: (1) Gavins Point Dam to near Ponca, Nebr. (hereinafter named "Gavins"); (2) Ponca to the confluence with the Big Sioux River (hereinafter named "Ponca"); (3) Big Sioux River to the confluence with the Platte River (hereinafter named "Big Sioux"); (4) the Platte River to the confluence with the Kansas River (hereinafter named "Platte"); (5) the Kansas River to the confluence with the Grand River (hereinafter named "Kansas"); (6) the Grand River to the confluence with the Osage River (hereinafter named "Grand"); and (7) the Osage River to the confluence with the Mississippi River (hereinafter named "Osage").

The longitudinal distribution of sand deposition on the flood plain along the lower Missouri River in 2011 (fig. 8) indicates depositional patterns were affected by annual peak streamflow magnitude, channel capacity, flood-plain confinement, sediment supply, and connectivity between channel and flood plain (fig. 8). The spatial distributions of overbank flooding and sand deposition on the lower Missouri River flood plain in 2011 are consistent with transport by floodwater that originated mostly from Gavins Point Dam, but did not substantially overflow the banks of the Missouri River until downstream from Sioux City, Iowa. Overbank flooding and sand deposition increased downstream from Sioux City to a broad peak near Rulo, Nebr. (fig. 1) (approximately RM 498), and then decreased to be intermittently near unmeasurable levels (lower limit of quantification using stated method) downstream from Kansas City, Mo. This broadly defined distribution parallels the pattern of incision and aggradation downstream from Gavins Point Dam (fig. 8E), a pattern that is related strongly to flood-plain connectivity (Jacobson and others, 2009).

The longitudinal variation in flood volume relative to channel capacity and magnitude of recent channel incision is evident from maximum flooded area and flood plain sand depositional area (fig. 8A, $B$ ). In the Gavins segment, despite the relatively low exceedance frequencies of 2011 annual peak streamflow magnitude, the incised, wide channel accommodated much of the floodwater, and overbank flooding was not 
A. 1993

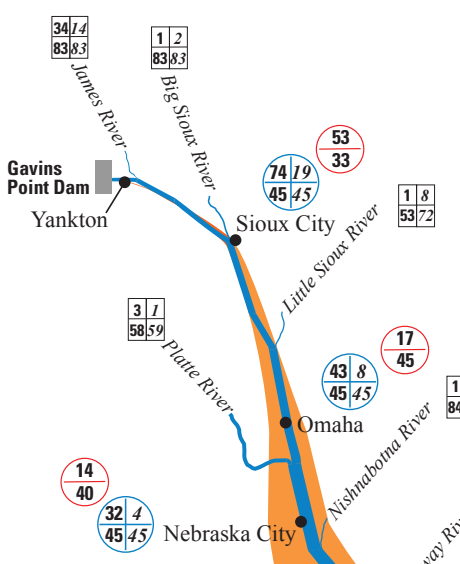

$\frac{1}{45}$

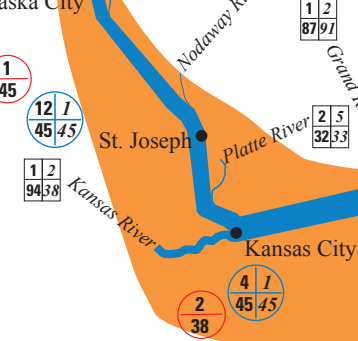

C. 2011

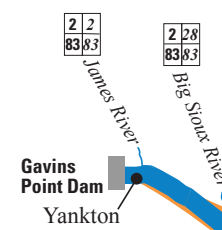

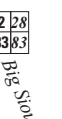

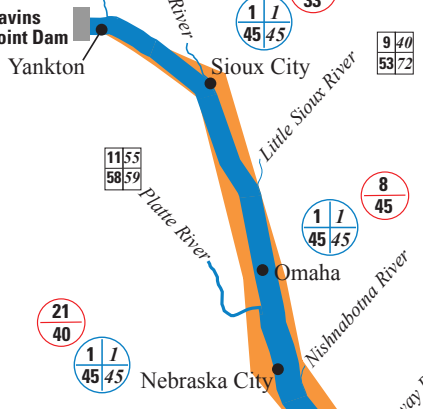

$\frac{63}{45}$

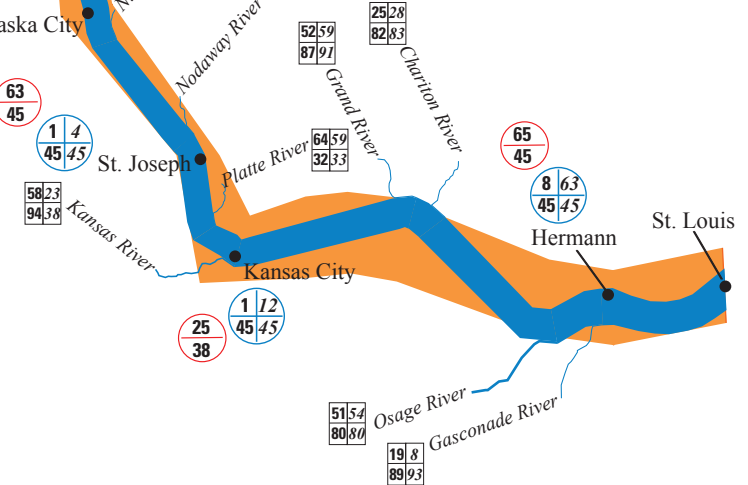

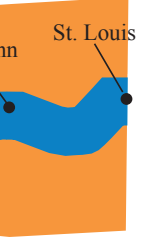

\begin{tabular}{r|r|}
\hline 128 \\
8080
\end{tabular}

\begin{tabular}{|l|l|}
\hline 95 \\
\hline 89 & 93 \\
\hline
\end{tabular}
B. 2008

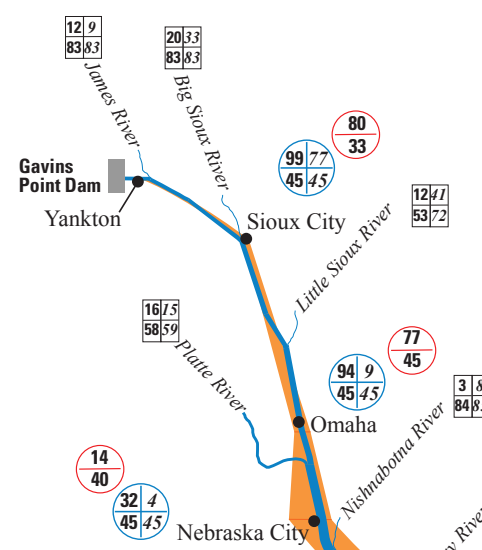

$\frac{1}{45}$

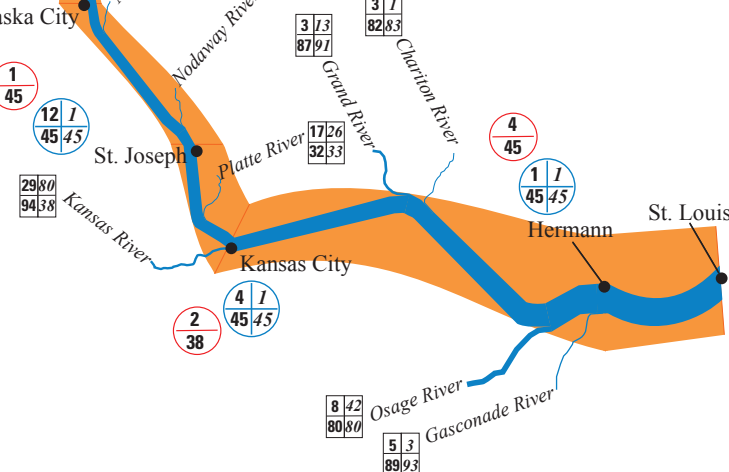

EXPLANATION

Total estimated suspended-sediment discharge, in millions of tons per year

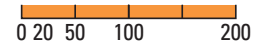

Estimated average annual streamflow,

in thousands of cubic feet per second

$$
0 \quad 200
$$

Lower Missouri River Basin streamgages

Annual average
streamflow percentile*

Number of years of 45 N5 Number of years of

streamflow record

$$
\begin{aligned}
& \text { - Annual sediment discharge } \\
& \text { percentile* } \\
& \text { Number of years of record }
\end{aligned}
$$

Tributary gaging station

Annual average
streamflow percentile*

Number of years of $>8993$ \umber of years of

streamflow record peak-flow record

* Percentiles based on Cunnane (1978) plotting position formula

Figure 6. Annual average streamflow for the lower Missouri River and major tributaries and annual total suspended-sediment discharge for selected main-stem streamgages, water years 1993, 2008, and 2011. Estimates of average annual streamflow for tributaries are represented by most downstream streamgage, and may differ from actual magnitudes shown. Estimates are compiled from USGS National Water Information System; Heimann and others, 2010; Dave Heimann (U.S. Geological Survey, written commun., 2012). Estimates of sediment discharge near St. Louis were assumed to be approximately equivalent to those at Hermann for illustrative purposes in this figure. 


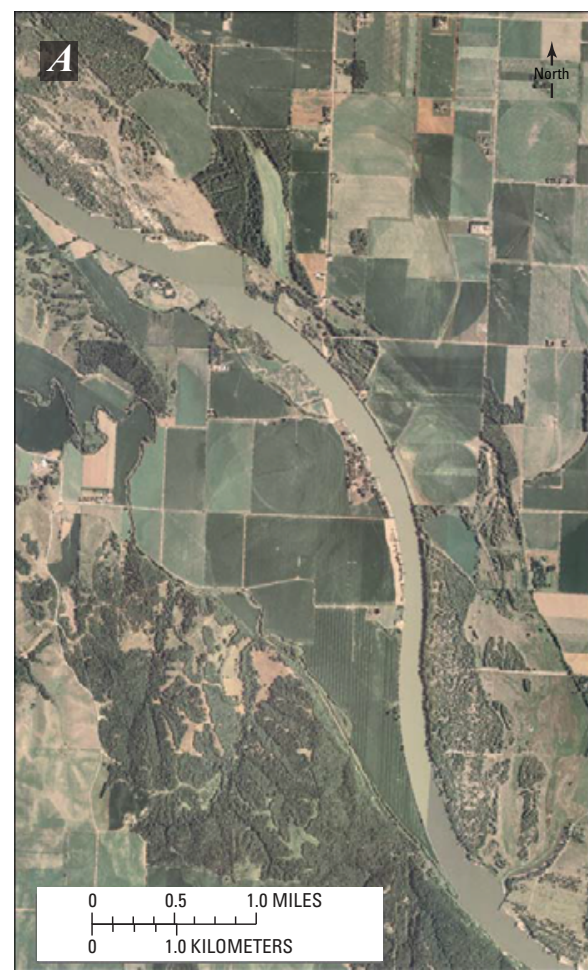

Base image from the United States Department of

Agriculture-National Agriculture Imagery Program, 2006

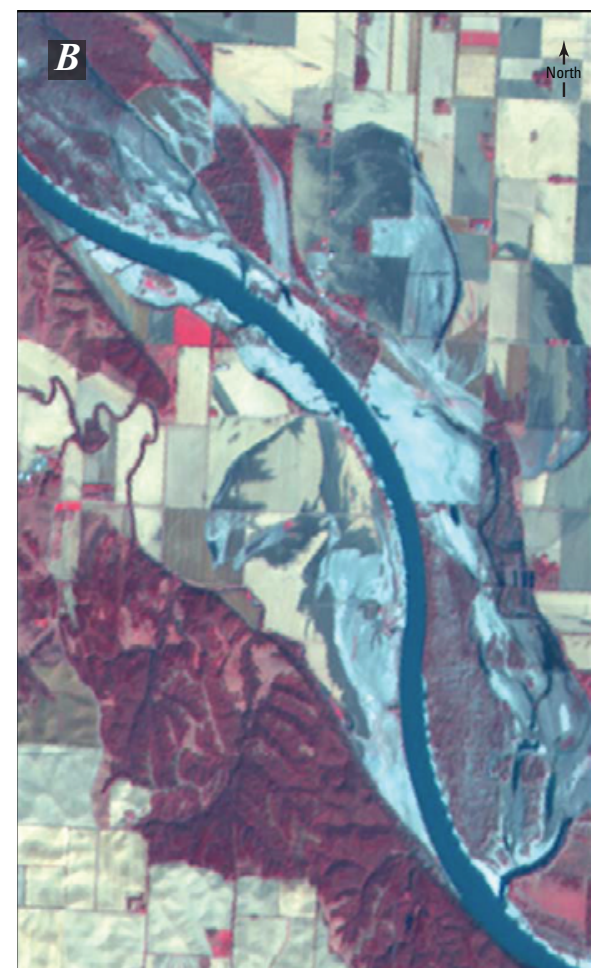

Base image is copyrighted from Centre National d'Etudes Spatiales, France, 2011

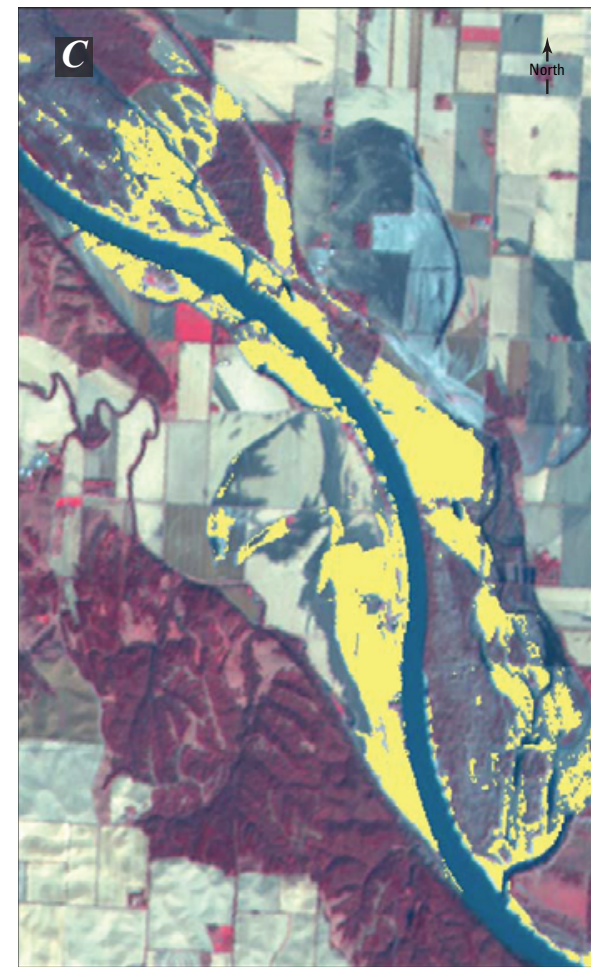

Base image is copyrighted from Centre National d'Etudes Spatiales, France, 2011

Figure 7. Images showing method of mapping sand deposition and deposited sand on the flood plain of the lower Missouri River, upstream of Sioux City, lowa, in Union County, lowa after the flood conditions of 2011. A, 2006 natural-color aerial photograph. B, Postflood multispectral image. $C$, Same image showing areas mapped as new sand deposits in yellow from supervised classification.

extensive. Overbank flooded area and sand depositional area increased in the Ponca segment, where channel capacity is reduced relative to the upstream reach, because the riverbed has undergone less degradation. Most of the flood-plain inundation and sediment-deposition damage to agricultural fields occurred between RM 480 and 700, where 2011 annual peak streamflows had low exceedance frequencies, and where the lower Missouri River channel is less incised or has aggraded in recent decades (fig. 8E), allowing floodwater easier access to the flood plain. As channel capacity increased in the downstream direction, the relative magnitude of the flood decreased downstream, overbank flooding was less extensive, and sand depositional area consequently decreased.

The spatial distribution of flood plain sand deposits also relates to the distribution of floodwalls and levees that mediate connection of the channel to the flood plain, and the broad, wave-like pattern of sand deposition is punctuated with local highs related to levee breaks (fig. 8D). Gaps in flood plain sand deposits exist between RM 720 and 735, coincident with flood walls protecting much of Sioux City, Iowa, and between RM 610 and 620, coincident with flood protection around Omaha, Nebr. Flood plain sand deposition also was affected by levee constrictions and levee breaks. Floodway constrictions by agricultural levees are highly variable. The distances between levees (or levees on one side and valley wall on the other) are relatively wide upstream from RM 620, whereas downstream from RM 620, overbank constricted widths decrease as a result of levee alignments close to the channel (fig. $8 D$ ).

The typical morphologies of small and large levee-break complexes have been interpreted by previous investigators (Jacobson, 2003) to indicate that levee breaks involved exceedance of at least one of three geomorphic thresholds, and those breaks that most effectively transported sediment onto the flood plain exceeded all three. The first threshold to be overcome is the energy threshold, inherent in exceedance or failure of the levee, which can happen by various processes, including overtopping (design exceedance), geotechnical slope failure, lateral erosion, or liquefaction through sand boils (fig. 9A, $B$ ). A second geomorphic threshold is the erosion threshold. The erosion threshold is exceeded when streamflow is concentrated through the levee-break opening, often at locally steepened slopes, and streamflow velocities are sufficient to erode through the cohesive top stratum of alluvial deposits (fig. 9C). Typical Missouri River flood plain deposits have a silt-clay top stratum of variable thickness that also serves as productive agricultural soil. When the top stratum is eroded by hydrodynamic forces concentrated through a leveebreak, turbulent floodwater gains access to the underlying noncohesive sand that is eroded easily, creating extensive floodplain scours. The flood-plain scours can constitute substantial damage to flood plain cropland, soils, and infrastructure, and also deliver additional sediment for downstream transport. The third threshold, a connectivity threshold, is exceeded when 


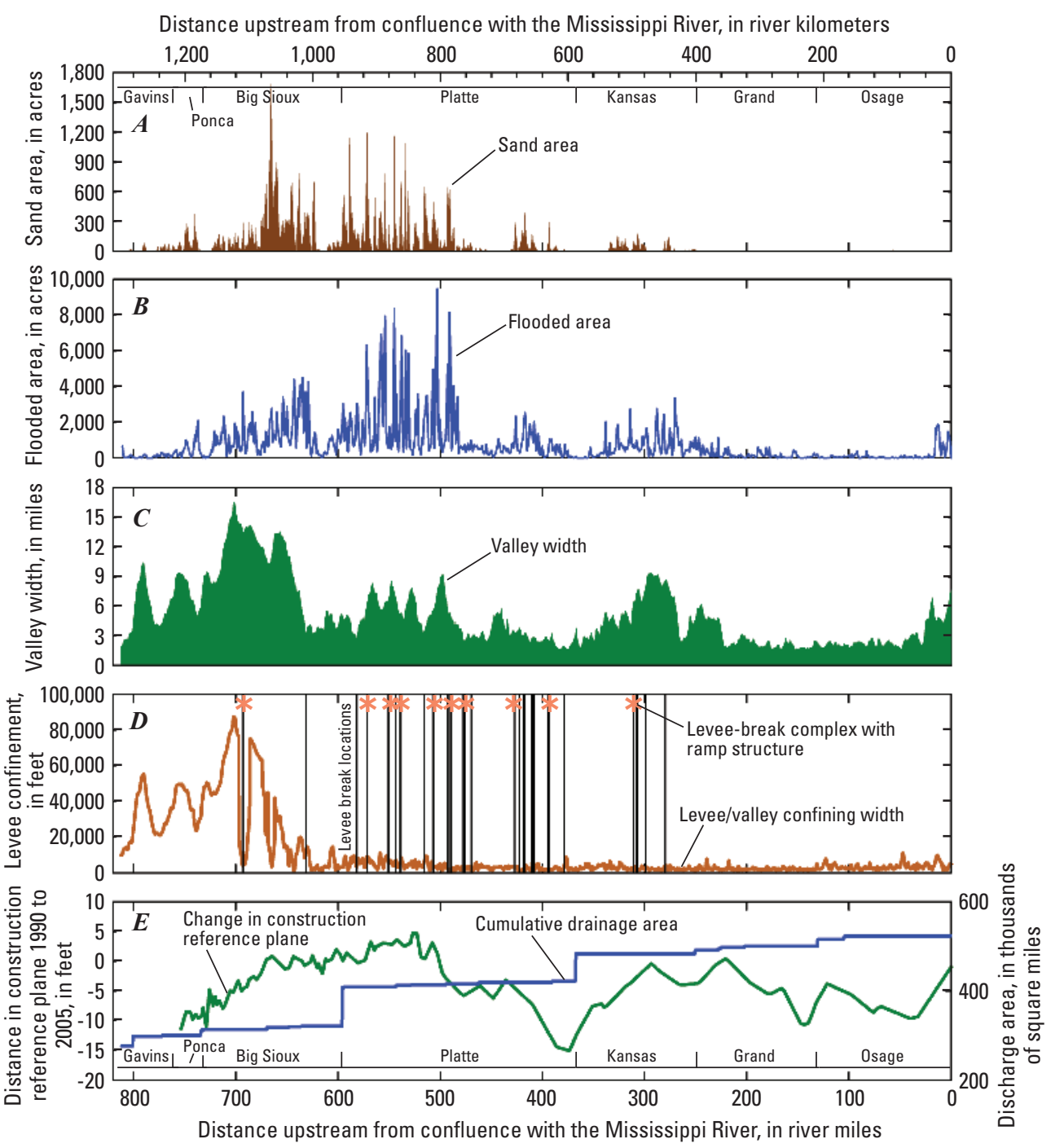

Figure 8. Longitudinal distribution of sand deposition and overbank flooding along the lower Missouri River in 2011 and potential covariates: $A$, area of sand deposits on valley bottom; $B$, peak flooded area along valley bottom; $C$, width of valley bottom; $D$, confinement of main-stem channel between levees or between a levee and valley wall, locations of levee breaks, and locations of levee-break complexes with ramp structures connecting the channel to the flood plain; $E$, change in Construction Reference Plane (a conceptual, water-surface-elevation plane for the streamflow having 75-percent exceedance frequency at all locations, based on U.S. Army Corps of Engineers, unpublished data) 1990-2005, showing areas of channel incision and aggradation (negative values indicate net degradation or incision), and cumulative downstream increase in drainage area, and cumulative total drainage area. River miles are based on unpublished data from the U.S. Army Corps of Engineers.

the scour hole downstream from the levee break has had sufficient time to erode upstream to connect to the main channel (fig. 9D). In this situation, the levee-break complex has created a ramp-like structure, allowing a direct path for suspended and bedload sediment to be transported from the main channel onto the flood plain. Approximately 10 levee-break complexes created by the 2011 flood on the lower Missouri River were interpreted to have progressed to this third stage (fig. 9).

In the constricted reaches, flood plain sand deposits are mainly located near levee breaks. As many as 33 separate levee breaks were observed on the lower Missouri River in 2011 (fig. $8 D$ ). Levee breaks concentrate streamflow, causing high current velocities across the flood plain, and creating distinctive sand splay deposits (fig. 10). The concentrated streamflow resulted in enhanced transport of sand onto the flood plain in these areas. Similar levee-break complexes were documented to have resulted from a large Missouri River/Mississippi River flood in 1993 (Jacobson and Oberg, 1997; Schalk and Jacobson, 1997; Jacobson, 2003), where some levee breaks were shown to be particularly effective in transporting sediment from the main channel onto flood plains. For example, a large levee-break complex on the Missouri River near Hermann, Mo., deposited 4.4 million cubic yards $\left(\mathrm{yd}^{3}\right)$ of sediment, equivalent to $10-16$ percent of the 

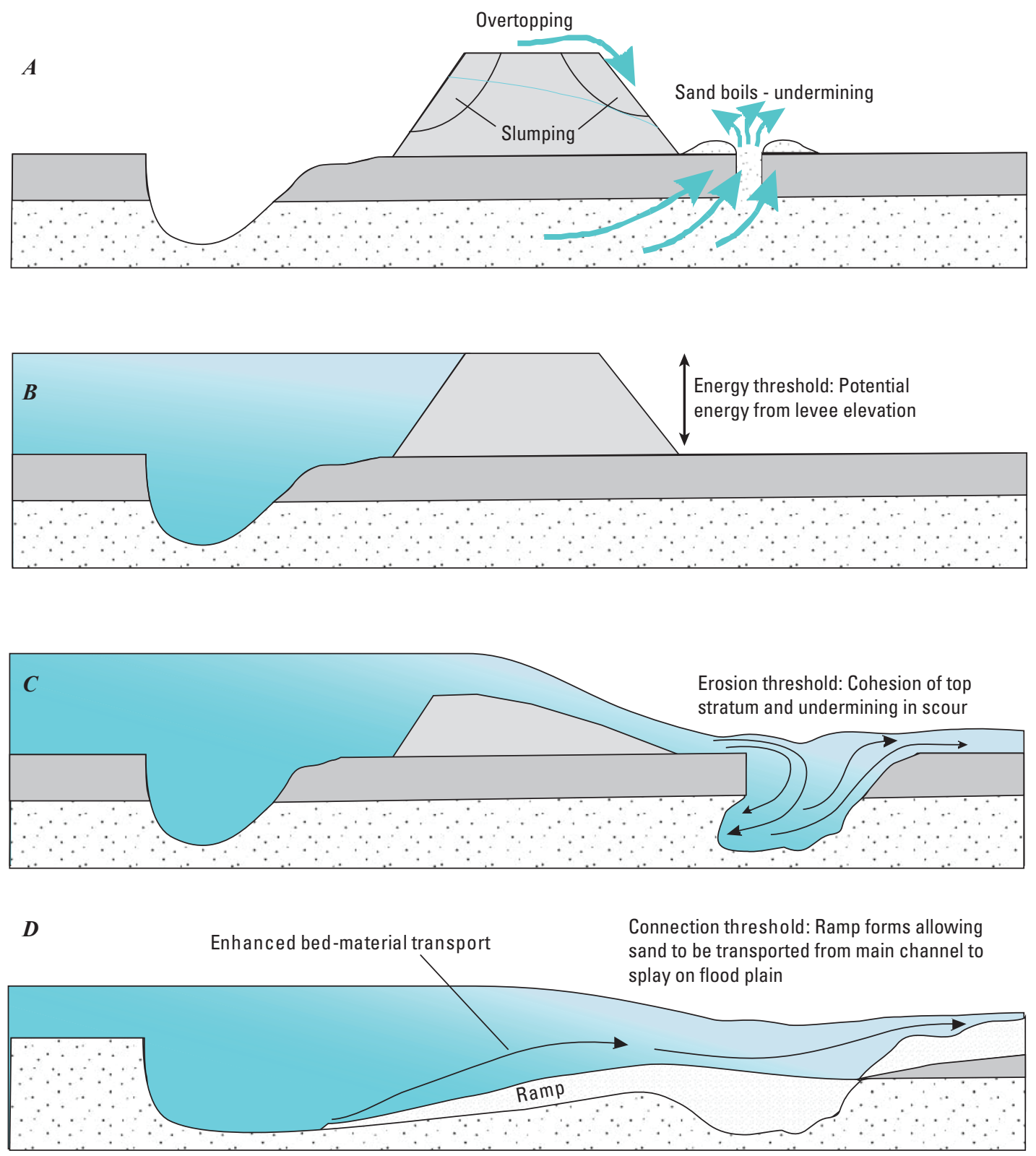

Figure 9. Conceptual diagrams showing progression of levee break: $A$, pre-levee-break situation, indicating variety of possible exceedance or failure mechanisms; $B$, levee height creates local potential energy; the levee creates a local threshold that, when exceeded, releases energy locally; $C$, an overtopped or failed levee concentrates streamflow, creating locally high velocities, resulting in flood-plain scour. Scour through a cohesive top stratum into underlying non-cohesive sand deposits is a second, erosional threshold that, once overcome, results in rapid upstream and downstream expansion of the flood-plain scour area; $D$, a third threshold, a connection threshold, happens when flood-plain scour extends upstream and intersects the main channel, resulting in direct, ramp-like access of suspended and traction sediment load onto the flood plain.

suspended-sediment load of the 1993 flood (Holmes, 1996; Schalk and Jacobson, 1997), and a complex on the Mississippi River near Miller City, Illinois, had a deposit of 10.7 million $\mathrm{yd}^{3}$, or 22-36 percent of the Mississippi River suspended-sediment load (Jacobson and Oberg, 1997). These volumes indicate that levee-break complexes can create substantial sinks for sediment during large floods, and are a likely explanation for downstream decreases in total SSD in 2011, such as those between Nebraska City and St. Joseph, and between Kansas City and Hermann (table 1). During the 1993 flood, Holmes (1996) reported substantial decreases in the suspended-sediment load between the Missouri River at Hermann and the Mississippi River at St. Louis, and attributed the decreases to a combination of sediment deposition on the Missouri River flood plain at levee breaks and the lower overall sedimenttransport capacity of the Mississippi River at St. Louis. 


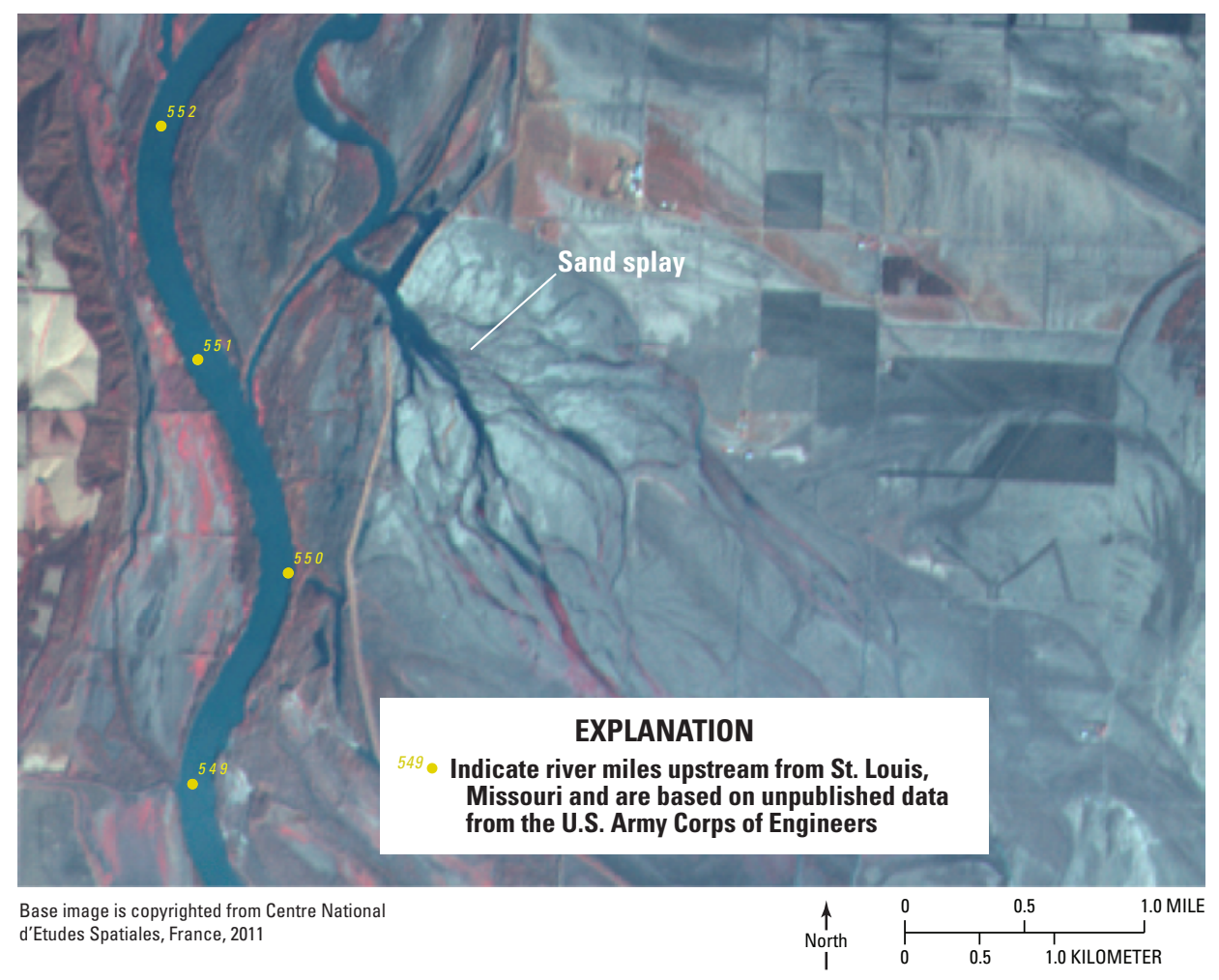

Figure 10. Multispectral satellite image taken in November 2011 showing a typical leveebreak complex formed in the valley bottom of the lower Missouri River during overbank flooding in 2011. Labels in yellow indicate river miles upstream from the confluence with the Mississippi River at St. Louis, Missouri, and are based on unpublished data from the U.S. Army Corps of Engineers.

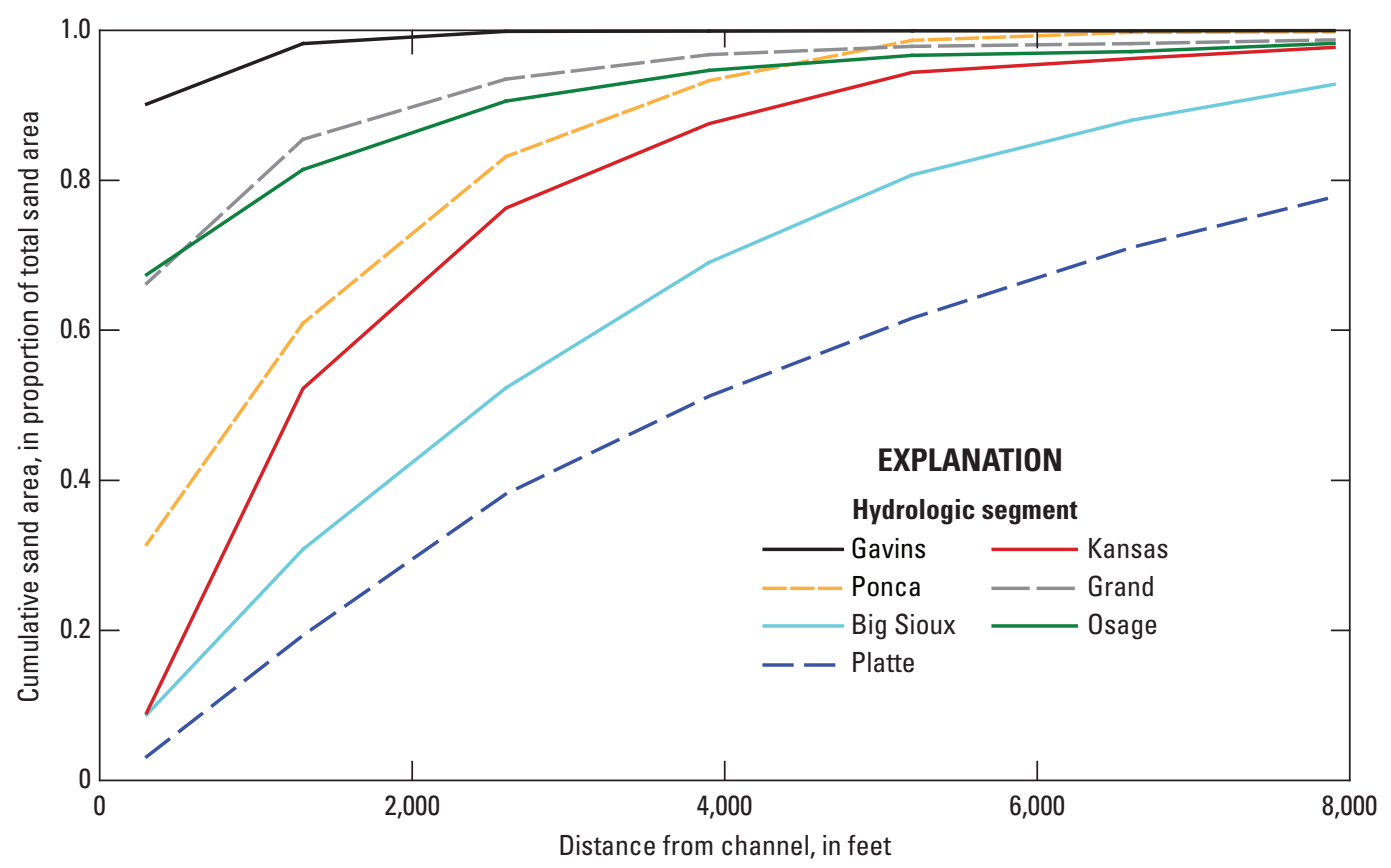

Figure 11. Cumulative sand depositional area by distance away from channel boundary in the valley bottom of seven hydrologic segments of the lower Missouri River after overbank flooding in 2011. Hydrologic segments are named for the upstream-bounding tributary or, in the case of Gavins, a large, main-stem dam bounding the segment at the upstream end. 
Analysis of the calculated distance of sand deposits from the main channel also indicates the effect of levee breaks on flood-plain sedimentation in the lower Missouri River in 2011. Sand deposition extended furthest from the river channel in the Big Sioux, Platte, and Kansas hydrologic segments, and was nearest to the channel in the Gavins, Ponca, Grand, and Osage segments. This pattern may be the result of a combination of the concentration of streamflow and current velocities in levee breaks, which enabled advection of sand further across the flood plain, and the generally wider valley width of these three reaches (fig. 8C). Sand deposition in the Platte segment, which had the greatest number of levee breaks, extended farther away from the channel than in upstream reaches with nearly equivalent, or greater, overall depositional areas per mile. For example, in the Platte segment, only 50 percent of the total sand-depositional area was accounted for within $4,000 \mathrm{ft}$ from the channel; however, at the same distance, approximately 70 and 80 percent of total sand-depositional area was accounted for in the Ponca and Big Sioux segments, respectively (fig. 11). The greater dispersion of sediment across the flood plain in the Platte segment relative to the Sioux and Ponca segments could also be the result of finer grain sizes in the suspendedsediment load being transported farther away from the channel; however, in the absence of grain-size data on the flood plain, this hypothesis could not be tested.

\section{Summary}

Flooding in the Missouri River Basin in 2011 was caused by a combination of above-normal snowpack in headwater regions in the Rocky Mountains of Montana and Wyoming, near record snowfall and wet soil conditions on the plains, and record rainfall in May across the upper Missouri River Basin. Floodwater originating in these upper-basin regions then travelled through the series of large flood-control reservoirs, setting records for total runoff volume entering all six Missouri River main-stem reservoirs in 2011, forcing releases from the dams. The flooding lasted as long as 3 months, and releases at Gavins Point Dam near Yankton, S. Dakota, the most downstream of the series of six large dams on the Missouri River main stem, were the largest measured in magnitude and volume since operations began in 1955. Sediment caused substantial damage to agricultural fields, homes, and infrastructure along the valley bottom adjacent to the river. The U.S. Geological Survey (USGS), in cooperation with the U.S. Army Corps of Engineers, examined sediment transport and deposition in the lower Missouri River in 2011 to investigate how the geography of floodwater sources, coupled with the along-stream characteristics of civil infrastructure and valley-bottom topography, affected characteristics of sediment transport and deposition in this large, regulated river system. During the flood conditions in 2011, the USGS, in cooperation with the U.S. Army Corps of Engineers, monitored suspendedsediment transport at six streamgages along the length of the lower Missouri River: (1) Sioux City, Iowa; (2) Omaha, Nebr.;
(3) Nebraska City, Nebr.; (4) St. Joseph, Mo.; (5) Kansas City, Mo.; and (6) Hermann, Mo.

Investigation of sediment transport and deposition focused on three key questions related to the unique combination of floodwater geography, magnitude, and volume in the lower Missouri River in 2011: (1) What were the temporal and spatial characteristics of sediment transport in the lower Missouri River in 2011? (2) How did floodwater geography differ from other high streamflow years in the lower Missouri River and did the difference cause detectable differences in sediment transport relative to previous years? (3) How did the longitudinal variation in channel geomorphology and civil infrastructure interact with floodwater geography to affect the spatial distribution and style of sediment deposition in the lower Missouri River valley?

Measured suspended-sediment concentration (SSC) in the lower Missouri River varied from approximately 150 milligrams per liter (mg/L) to 2,000 $\mathrm{mg} / \mathrm{L}$ from January 1 through September 30, 2011. Median SSC increased in the downstream direction from $355 \mathrm{mg} / \mathrm{L}$ at Sioux City to 490 $\mathrm{mg} / \mathrm{L}$ at Hermann. The highest concentrations were measured downstream from Omaha in late February, when snowmelt runoff from tributaries draining zones of high sediment production was entering the lower Missouri River, and releases at Gavins Point Dam (Gavins Point Dam) were small. Variability in SSC also increased in the downstream direction, except at Hermann. From mid-June through August 20, while releases at Gavins Point Dam were sustained at or above 150,000 cubic feet per second, measured SSC decreased at all selected streamgages to levels between approximately 115 to $250 \mathrm{mg} / \mathrm{L}$ below observed station-median values. The combination of dilute releases at Gavins Point Dam and stable, low flows in tributaries caused sustained lowering of SSC at all streamgages from early July through late August, despite the high-magnitude streamflows along the main stem. SSC observations at most streamgages increased slightly and temporarily when releases at Gavins Point Dam began to decrease in late August, and again in mid-September.

Measured percent washload (PW) of suspended sediment ranged from 5 percent to as much as 98 percent in the lower Missouri River from January 1 to September 30, 2011. Median PW increased in the downstream direction from 24 percent at Sioux City to 78 percent at Hermann. Measurements made in early January, when SSC was low, indicate that suspended sediment mostly was composed of bed material (PW ranged from 5 to 33 percent). In mid-February, snowmelt runoff from the plains began to contribute streamflow to the lower Missouri River, and PW increased at most stations, ranging from 20 to 85 percent, indicating that early spring runoff was carrying mainly washload into the lower Missouri River. After spring runoff began, $\mathrm{PW}$ was variable at most stations, fluctuating in response to spikes in tributary flows as well as clear-water releases at Gavins Point Dam.

Total suspended-sediment discharge (SSD) during water year 2011 at the selected streamgages in the lower Missouri River ranged from approximately 29 to 64 million tons. Total 
estimated SSD had the lowest exceedance frequencies in the reaches between Gavins Point Dam and Nebraska City, but exceedance frequencies increased substantially downstream. Annual total SSDs with low exceedance frequencies were reported at Sioux City, Omaha, and Nebraska City in 2011 despite moderate-to-high exceedance frequencies for average SSC, indicating that the duration of high-magnitude flooding was the primary driver of total SSD. Exceedance frequencies of annual average streamflow in 2011 in the lower Missouri River from Sioux City to Hermann were all approximately within the highest percentile of streamflow for the period of record. Despite small exceedance frequencies for 2011 total streamflow throughout the system, exceedance frequencies of total SSD increased from 2 percent at Sioux City to 65 percent at Hermann.

The signature of reservoir decanting on SSC in the lower Missouri River in water year 2011 was evident in the frequency distributions of SSC for low- and high-action streamflows (respectively, streamflows producing stages lower and higher than the National Weather Service "action stages") at the selected streamgages, relative to those for similar streamflows in the previous 20 years. Differences between median SSC for samples during high-action streamflows in 2011 and those for the selected period of record ranged from approximately $170 \mathrm{mg} / \mathrm{L}$ to $1,010 \mathrm{mg} / \mathrm{L}$, whereas differences between high-action streamflow samples from 2011 and samples during low-action streamflows in the previous 20 years ranged from approximately $0 \mathrm{mg} / \mathrm{L}$ to $340 \mathrm{mg} / \mathrm{L}$. Multiple-comparison analysis indicated that median SSC values for low- and highaction streamflows sampled in 2011 at 4 of 6 monitoring stations were not significantly distinguishable from median SSC values for low-action streamflows in the previous 20 years.

Longitudinal comparison of streamflow and annual total sediment-discharge exceedance frequencies for 2011 with corresponding frequencies for 2008 and 1993 showed the important role of tributary contributions to annual total SSD and the effect of clear-water releases on total SSD in 2011. In 1993 and 2008, exceedance frequencies for annual average and annual peak streamflow decreased substantially from upstream to downstream. In contrast, exceedance frequencies for annual average and annual peak streamflow at the selected streamgages in 2011 increased from upstream to downstream. The pattern of downstream increasing exceedance frequencies for streamflow highlights the downstream diminishing effect of tributaries on 2011 flood flows in the lower Missouri River relative to releases at Gavins Point Dam. Exceedance frequencies of annual peak streamflows in major tributaries to the lower Missouri River were generally low in 2011, but 6 of 12 major tributaries had exceedance frequencies of 40 percent or greater, and 4 had frequencies greater than 50 percent. Differences between relative streamflow contributions from Gavins Point Dam releases and downstream tributaries in 1993, 2008, and 2011 translated into real differences in total SSD along the lower Missouri River. In 1993 and 2008, tributaries were the primary source of floodwater in the lower Missouri River, which resulted in a 20-fold increase in total SSD from Sioux
City to Hermann. In 2011, releases at Gavins Point Dam were the primary source of floodwater, and annual total SSD at Hermann was only twice that estimated for Sioux City.

Sand deposition along the flood plain of the lower Missouri River was estimated to assess sediment-related geomorphic effects and damages. Sand deposition was estimated using analysis of multispectral satellite imagery collected in October and November 2011 along the entire 811 miles of the lower Missouri River. The distributions of sand deposits along the flood plain of the lower Missouri River also were analyzed in relation to distance from the banks of the main channel by summing the area of sand within progressively wider bufferdistance swaths, and subtotaled for seven discrete hydrologic segments. The seven hydrologic segments, bounded by Gavins Point Dam and selected downstream tributaries, were named for their upstream-bounding dam or tributary: (1) Gavins,

(2) Ponca, (3) Big Sioux, (4) Platte, (5) Kansas, (6) Grand, and (7) Osage.

The spatial distributions of overbank flooding and sand deposition on the lower Missouri River flood plain in 2011 are consistent with transport by floodwater that originated mostly from Gavins Point Dam, but did not substantially overflow the banks of the Missouri River until downstream from Sioux City, Iowa. Overbank flooding and sand deposition increased downstream from Sioux City to a broad peak near Rulo, Nebr., and then decreased to levels near the lower limit of quantification downstream from Kansas City. Most of the flood-plain inundation and sediment-deposition damage to agricultural fields was observed between river miles 480 and 700, where 2011 annual peak streamflows had low exceedance frequencies, and where the lower Missouri River channel is less incised or has aggraded in recent decades, allowing floodwater easier access to the flood plain. As channel capacity increased in the downstream direction, the relative magnitude of the flood decreased downstream, and overbank flooding was less extensive. Gaps in flood plain sand deposits exist between river miles 720 and 735 , coincident with flood walls protecting much of Sioux City, Iowa, and between river miles 610 and 620 , coincident with flood protection around Omaha, Nebr.

Flood plain sand deposition also was affected by levee constrictions and levee breaks. In the constricted reaches, flood plain sand deposits were mainly located near levee breaks. The levee breaks concentrated streamflow, causing high local current velocities and enhanced transport of sand onto the flood plain. Sand deposition extended furthest from the river channel in the Big Sioux, Platte, and Kansas segments, and was nearest to the channel in the Gavins, Ponca, Grand, and Osage segments. Sand deposition in the Platte segment, which had the greatest number of levee breaks, extended further away from the channel than upstream reaches with nearly equivalent, or greater, overall depositional areas per mile. Approximately 10 levee-break complexes created by the 2011 flood on the lower Missouri River were interpreted to have developed when conditions exceeded three geomorphic thresholds, and water flowing through a levee break advected large volumes of sand onto the flood plain. 


\section{References Cited}

Blevins, D.W., 2006, The response of suspended sediment, turbidity, and velocity to historical alterations of the Missouri River: U.S. Geological Survey Circular 1301, 8 p.

Blevins, D.W., 2011, Water-quality requirements, tolerances, and preferences of pallid sturgeon (Scaphirhynchus albus) in the lower Missouri River: U.S. Geological Survey Scientific Investigations Report 2011-5186, 20 p.

Chojnacki, K.A., Struckhoff, M.A., and Jacobson, R.B., 2012, Land capability potential index (LCPI) and geodatabase for the lower Missouri River valley: U.S. Geological Survey Data Series 736, 18 p.

Church, M., 2006, Bed material transport and the morphology of alluvial river channels: Annual Reviews in Earth and Planetary Science, v. 34, p. 325-354.

Coker, E.H., Hotchkiss, R.H., and Johnson, D.A., 2009, Conversion of a Missouri River dam and reservoir to a sustainable system - Sediment management: Journal of the American Water Resources Association, v. 45, p. 815-827.

Cunnane, C., 1978, Unbiased plotting positions-A review: Journal of Hydrology, v. 37, p. 205-322.

Davis, B.E., 2005, A guide to the proper selection and use of federally approved sediment and water-quality samplers: U.S. Geological Survey Open-File Report 2005-1087, 20 p.

Dixon, M.D., Johnson, W.C., Scott, M.L., and Bowen, D., 2010, Status and trend of cottonwood forests along the Missouri River: Final report to the U.S. Army Corps of Engineers, $111 \mathrm{p}$.

Edwards, T.K., and Glysson, G.D., 1999, Field methods for measurement of fluvial sediment: U.S. Geological Survey Techniques of Water-Resources Investigations, book 3 , chap. C2, 89 p.

Elliott, C.M., and Jacobson, R.B., 2006, Geomorphic classification of channel dynamics in the Missouri National Recreational, South Dakota and Nebraska: U.S. Geological Survey Scientific Investigations Report 2006-5313, 66 p.

Environmental Systems Research Institute, Inc. (ESRI), 2010, ArcGIS Desktop Version 10.0: Redlands, California.

Fenneman, N.M., 1928, Physiographic divisions of the United States: Annals of the Association of American Geographers, v. 17, p 261-353.

Funk, J.L., and Robinson, J.W., 1974, Changes in the channel of the lower Missouri River and effects on fish and wildlife: Jefferson City, Mo., Missouri Department of Conservation Aquatic Series 11, 52 p.
Galloway, J.M., Rus, D.L., and Alexander, J.S., 2013, Characteristics of sediment transport at selected sites along the Missouri River during the high-flow conditions of 2011: U.S. Geological Survey Scientific Investigations Report 2013-5006, 31 p.

Graf, W.L., Wohl, E., Sinha, T., and Sabo, J.L., 2010, Sedimentation and sustainability of western American reservoirs: Water Resources Research, v. 46, no. 12, citation number W12535, doi:10.1029/2009WR008836, accessed February 2, 2013.

Grigg, N., McCarthy, C., Lawrence, B., Ockerman, D., 2012, Review of the regulation of the Missouri River main-stem reservoir system during the flood of 2011: Missouri River Independent Review Panel report to the U.S. Army Corps of Engineers, Omaha District, 93 p.

Guy, H.P., 1969, Laboratory theory and methods for sediment analysis: U.S. Geological Survey Techniques of WaterResources Investigations, book 5, chap. C1, 58 p.

Hallberg, O.P., Harbaugh, J.M., and Witinok, P.M., 1979, Changes in the channel area of the Missouri River in Iowa, 1879-1976: Iowa Geological Survey Special Report Series, no. $1,32 \mathrm{p}$.

Heimann, D.C., Rasmussen, P.P., Cline, T.L., Pigue, L.M., and Wagner, H.R., 2010, Characteristics of sediment data and annual suspended-sediment loads and yields for selected lower Missouri River main-stem and tributary stations, 1976-2008: U.S. Geological Survey Data Series 530, 58 p.

Heimann, D.C., Sprague, L.A., and Blevins, D.W., 2011, Trends in suspended-sediment loads and concentrations in the Mississippi River Basin, 1950-2009: U.S. Geological Survey Scientific Investigations Report 2011-5200, 33 p.

Helsel, D.R., and Hirsch, R.M., 2002, Statistical methods in water resources: U.S. Geological Survey Techniques of Water-Resources Investigations, book 4, chap. A3, 523 p.

Holmes, R.R., 1996, Sediment transport in the lower Missouri and the central Mississippi Rivers-June 26 through September 14, 1993: U.S. Geological Survey Circular 1120-I, $23 \mathrm{p}$.

Holmes, R.R., Jr., Koenig, T.A., and Karsten, K.A., 2010, Flooding in the United States Midwest, 2008: U.S. Geological Survey Professional Paper 1775, 64 p.

Holmes, R.R., Jr., Wiche, G.J., Koenig, T.A., and Sando, S.K., 2013, Peak streamflows and runoff volumes for the central United States, February through September, 2011: U.S. Geological Survey Professional Paper 1798-C, 60 p. 
Horowitz, A.J., 2003, An evaluation of sediment rating curves for estimating suspended-sediment concentrations for subsequent flux calculations: Hydrological Processes, v. 17, p. 3387-3409.

Hubbell, D.W., and Stevens, H.H., 1986, Cascade-sieve shaker for rapid particle-size analysis of coarse sediment, in Subitzky, S., Selected papers in the hydrologic sciences, 1986: U.S. Geological Survey Water Supply Paper 2310, p. $73-85$.

Jacobson, R.B., 2003, Geomorphic effects in levee-break complexes and implications for flood-damage assessment, in Jacobson, R.B., Wilson, D.A., and Criss, R.E., eds., At the confluence; rivers, floods and water quality in the St. Louis region: St. Louis, Missouri, Botanical Gardens Press, p. 135-148.

Jacobson, R.B., Blevins, D.W., and Bitner, C.J., 2009, Sediment regime constraints on river restoration-An example from the lower Missouri River: Geological Society of America Special Paper 451, p. 1-22.

Jacobson, R.B., Chojnacki, K.A., and Reuter, J.M., 2007, Land capability potential index (LCPI) for the lower Missouri River valley: U.S. Geological Survey Scientific Investigations Report 2007-5256, 19 p.

Jacobson, R.B., and Oberg, K.A., 1997, Geomorphic changes on the Mississippi River flood plain at Miller City, Illinois, as a result of the flood of 1993: U.S. Geological Survey Circular 1120-J, 22 p.

Junk, W.J., Bayley, P.B., and Sparks, R.E., 1989, The flood pulse concept in river-flood plain systems: Canadian Special Publication of Fisheries and Aquatic Science, v. 106, p. $110-117$.

Langbein, W.B., and Schumm, S.A., 1958, Yield of sediment in relation to mean annual precipitation: Transactions of the American Geophysical Union, v. 39, p. 1076-1084.

Lorenz, D.L., and others, 2011, USGS library for S-PLUS for Windows-Release 4.0: U.S. Geological Survey Open-File Report 2011-1130 (Also available at http://water.usgs.gov/ software/S-PLUS/.)

Meade, R.H., ed., 1995, Contaminants in the Mississippi River, 1987-92: U.S. Geological Survey Circular 1133, $140 \mathrm{p}$.

Meade, R.H., and Moody, J.A., 2010, Causes for the decline of suspended-sediment discharge in the Mississippi River system, 1940-2007: Hydrological Processes, v. 24, p. 35-49.

National Research Council, 2002, The Missouri River ecosystem-Exploring the prospects for recovery: Washington, D.C., National Academies Press, 188 p.
National Research Council, 2011, Missouri River planningRecognizing and incorporating sediment management: Washington, D.C., National Academies Press, 152 p.

Parrett, C., Melcher, N.B., and James, R.W., Jr., 1993, Flood streamflows in the upper Mississippi River Basin, 1993: U.S. Geological Survey Circular 1120-A, 14 p.

Porterfield, G., 1972, Computation of fluvial-sediment discharge: U.S. Geological Survey Techniques of WaterResources Investigations, book 3, chap. C3, 66 p.

Rasmussen, P.P., Gray, J.R., Glysson, G.D., and Ziegler, A.C., 2009, Guidelines and procedures for computing time-series suspended-sediment concentrations and loads from instream turbidity-sensor and streamflow data: U.S. Geological Survey Techniques and Methods, book 3, chap. C4, $54 \mathrm{p}$.

Runkel, R.L., Crawford, C.G., and Cohn, T.A., 2004, Load Estimator (LOADEST) - A FORTRAN program for estimating constituent loads in streams and rivers: U.S. Geological Survey Techniques and Methods, book 4, chap. A5, 69 p.

Schalk, G.K., and Jacobson, R.B., 1997, Scour, sedimentation, and sediment characteristics at six levee-break sites in Missouri from the 1993 Missouri River flood: U.S. Geological Survey Water-Resources Investigations Report 97-4110, $72 \mathrm{p}$.

Schmidt, J.C., and Wilcock, P.R., 2008, Metrics for assessing the downstream effects of dams: Water Resources Research, v. 44, W04404, accessed June 1, 2010, at http://www.agu. org/journals/wr/wr0804/2006WR005092/2006WR005092. $p d f$.

Scott, M.L., Freidman, J.M., and Auble, G.T., 1996, Fluvial processes and the establishment of bottomland trees: Geomorphology, v. 14, p. 237-339.

U.S. Army Corps of Engineers, 2006, Missouri River mainstem reservoir system, Master water control manualMissouri River Basin: Omaha, Nebr., U.S. Army Corps of Engineers-Northwestern Division, Reservoir Control Center, [variously paged].

U.S. Army Corps of Engineers, 2009, Louisiana coastal protection and restoration: New Orleans, U.S. Army Corps of Engineers, Final technical report and comment addendum [variously paged].

U.S. Department of Agriculture, 2012, Assessment of the effects of conservation practices on cultivated cropland in the Missouri River Basin: Natural Resources Conservation Service, Conservation Effects Assessment Project Report, $225 \mathrm{p}$. 
U.S. Geological Survey, 2012a, Water-resources data for the United States, water year 2011: U.S. Geological Survey Water-Data Report WDR-US-2011, site 069345000, accessed December 2012, at http://wdr.water.usgs.gov/ wy2011/pdfs/06934500.2011.pdf.

U.S. Geological Survey, 2012b, National Water Information System (NWISWeb): U.S. Geological Survey database, accessed December 2012, at http://waterdata.usgs.gov/nwis.

Vining, K.C., Chase, K.J., and Loss, G.R., 2013, General weather conditions and precipitation contributing to the 2011 flooding in the Mississippi River and Red River of the North Basins, December 2010 through July 2011: U.S. Geological Survey Professional Paper 1798-B, 22 p.

Wahl, K.L., Vining, K.C., and Wiche, G.J., 1993, Precipitation in the upper Mississippi River Basin, January 1 through July 31, 1993: U.S. Geological Survey Circular 1120-B, $13 \mathrm{p}$.

Publishing support provided by:

Rolla Publishing Service Center

For more information concerning this publication, contact: Chief, USGS Office of Surface Water

415 National Center

12201 Sunrise Valley Drive

Reston, VA 20192

(703) 648-5301

Or visit the Office of Surface Water Web site at: http://water.usgs.gov/osw/ 




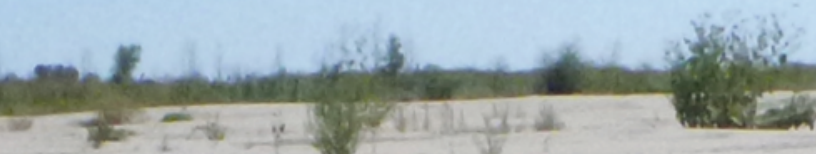

